WHC-EP-0796

UC-600

\title{
Ferrocyanide Safety Program: Data Interpretation Report for Tank 241-T-107 Core Samples
}

\author{
L. M. Sasaki \\ B. D. Valenzuela
}

Date Published

August 1994

Prepared for the U.S. Department of Energy

Office of Environmental Restoration and

Waste Management

\section{Q2. Westinghouse P.O. Box 1970}

W Hanford Company Richland, Washington 99352

Hanford Operations and Engineering Contractor for the

U.S. Department of Energy under Contract DE-AC06-87RL10930 


\section{DISCLAIMER}

This report was prepared as an account of work sponsored by an agency of the United States Government. Neither the United States Government nor any agency thereof, nor any of their employees, make any warranty, express or implied, or assumes any legal liability or responsibility for the accuracy, completeness, or usefulness of any information, apparatus, product, or process disciosed, or represents that its use would not infringe privately owned rights. Reference herein to any specific commercial product, process, or service by trade name, trademark, manufacturer, or otherwise does not necessarily constitute or imply its endorsement, recommendation, or favoring by the United States Government or any agency thereof. The views and opinions of authors expressed herein do not necessarily state or reflect those of the United States Government or any agency thereof. 


\section{DISCLAIMER}

Portions of this document may be illegible in electronic image products. Images are produced from the best available original document. 


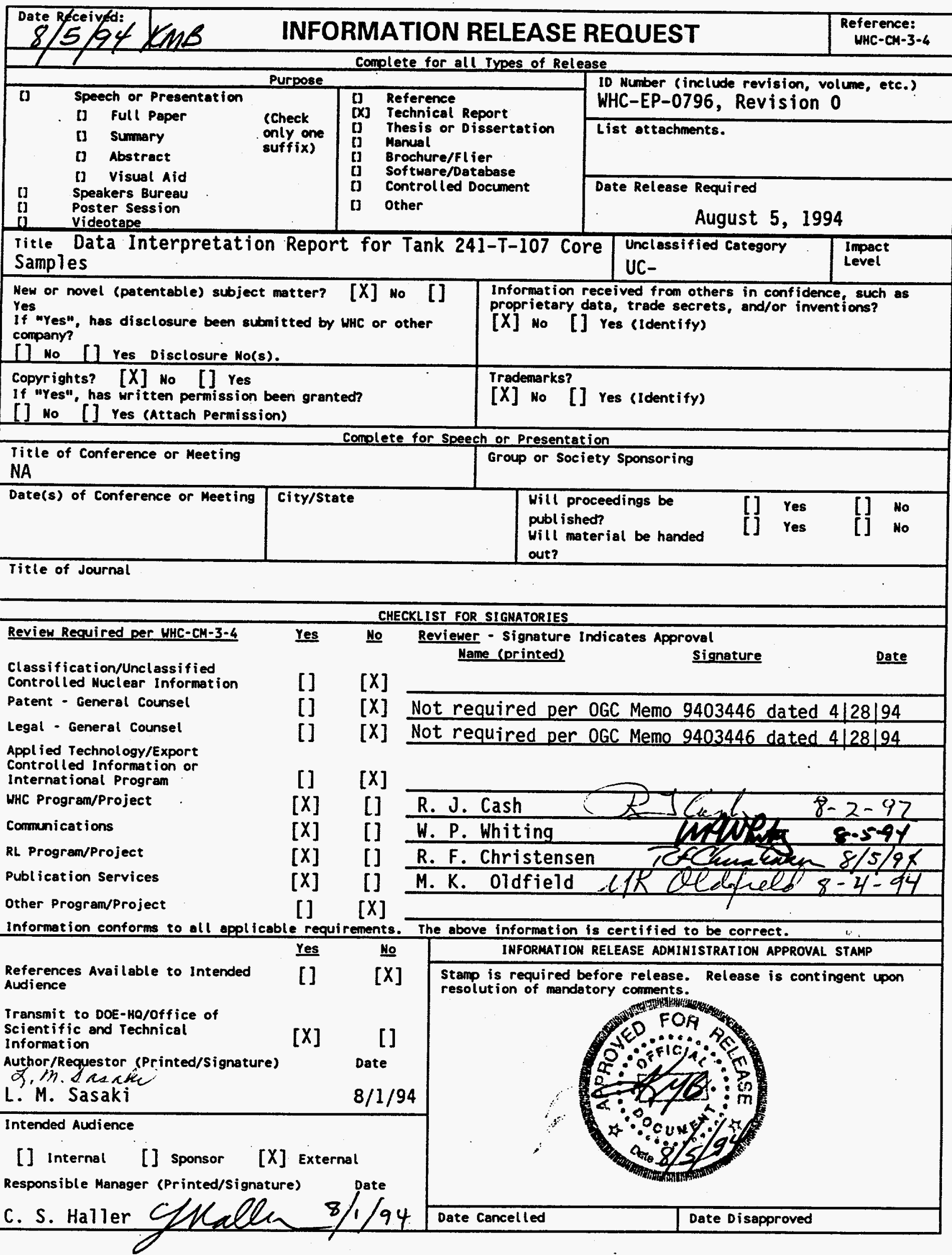




\section{CONTENTS}

1.0 INTRODUCTION $\ldots \ldots \ldots \ldots \ldots \ldots \ldots \ldots \ldots \ldots \ldots \ldots \ldots$

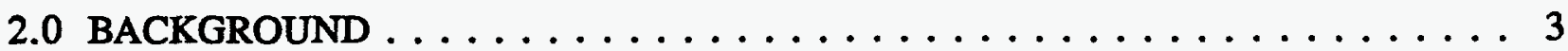

2.1 TANK $241-$ T-107 HISTORY $\ldots \ldots \ldots \ldots \ldots \ldots \ldots \ldots \ldots$

2.2 FERROCYANIDE ISSUE DATA QUALITY OBJECTIVES . . . . . . . 3

3.0 SAMPLE HANDLING AND ANALYTICAL PROCESS $\ldots \ldots \ldots \ldots \ldots \ldots$

3.1 TANK SAMPLING $\ldots \ldots \ldots \ldots \ldots \ldots \ldots \ldots \ldots$

3.2 CORE SAMPLE DESCRIPTIONS $\ldots \ldots \ldots \ldots \ldots \ldots \ldots$

3.3 SAMPLE PREPARATION $\ldots \ldots \ldots \ldots \ldots \ldots \ldots$

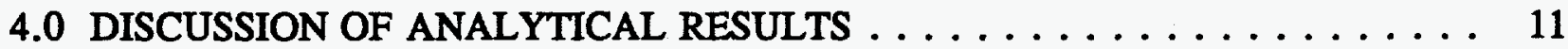

4.1 THERMAL ANALYSIS $\ldots \ldots \ldots \ldots \ldots \ldots \ldots \ldots \ldots \ldots$

4.1.1 Differential Scanning Calorimetry . . . . . . . . . . 11

4.1.2 Thermogravimetric Analysis And Gravimetric Analysis . . . . . 12

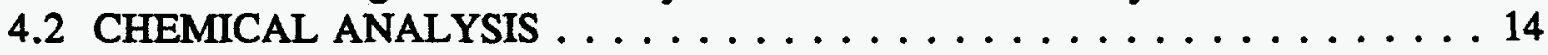

4.2.1 Cyanide Analysis . . . . . . . . . . . . . . 14

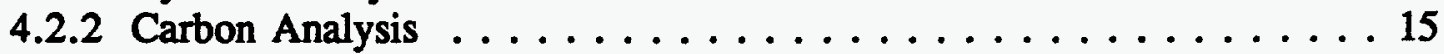

4.2.3 Inductively Coupled Plasma Analysis $\ldots \ldots \ldots \ldots \ldots \ldots \ldots$

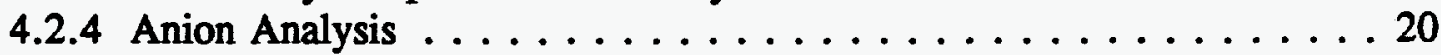

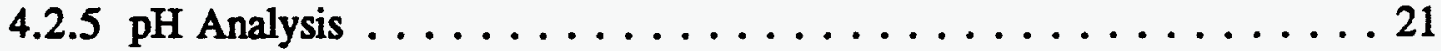

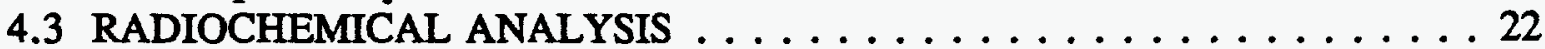

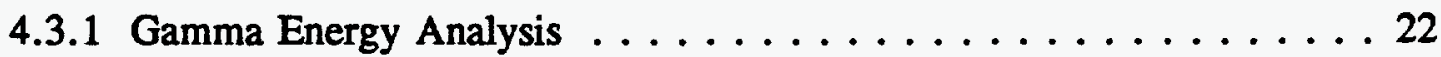

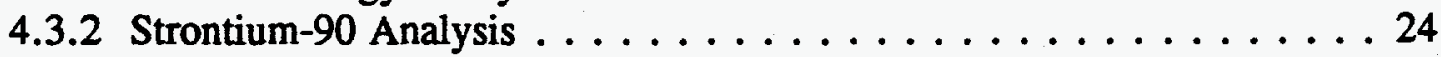

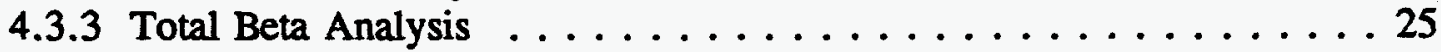

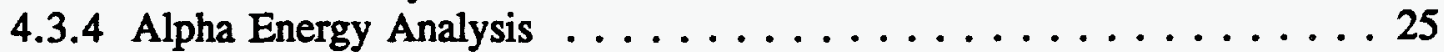

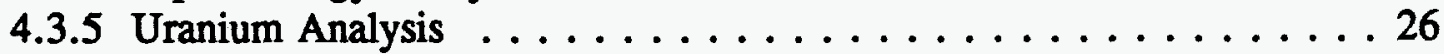

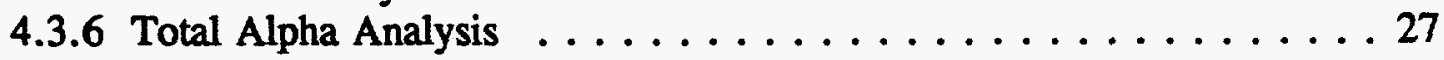

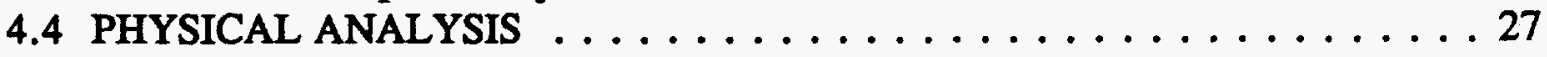

5.0 CONCLUSIONS AND RECOMMENDATIONS . . . . . . . . . . . . 29

6.0 REFERENCES $\ldots \ldots \ldots \ldots \ldots \ldots \ldots \ldots \ldots \ldots \ldots \ldots \ldots \ldots \ldots \ldots \ldots \ldots$ 


\section{LIST OF TABLES}

2-1 Primary and Secondary Data Requirements for Ferrocyanide Tanks . . . . . . . 4

2-2 Tertiary Data Requirements for Ferrocyanide Tanks $\ldots \ldots \ldots \ldots \ldots$

3-1 Sample Descriptions $\ldots \ldots \ldots \ldots \ldots \ldots \ldots \ldots \ldots \ldots$

3-2 Volumetric Sample Recovery $\ldots \ldots \ldots \ldots \ldots \ldots \ldots \ldots$

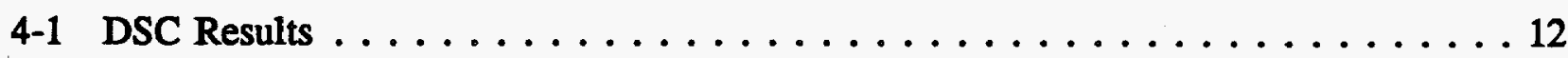

4-2 Percent Water Results From Thermogravimetric Analysis and Gravimetric Analysis . . . . . . . . . . . . . . . . . . 13

4-3 Cyanide Results . . . . . . . . . . . . . . . . . . 14

4-4 Total Carbon, Total Inorganic Carbon, and Total Organic Carbon Results for Segments and Subsegments . . . . . . . . . . . . . . 16

4-5 Total Carbon, Total Inorganic Carbon, and Total Organic Carbon Results for Drainable Liquids and Core Solids Composites . . . . . . . . . 17

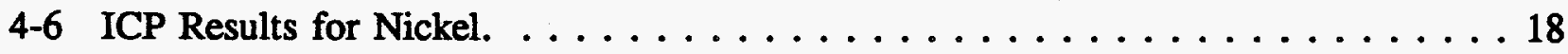

4-7 ICP Results for Aluminum, Calcium, Iron, Sodium, and Phosphorus . . . . . . 19

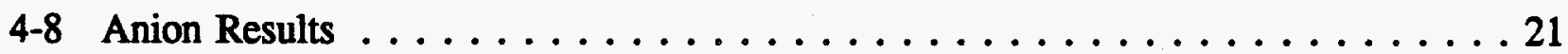

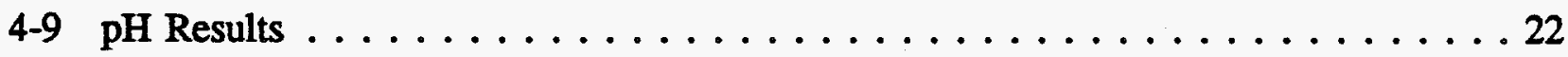

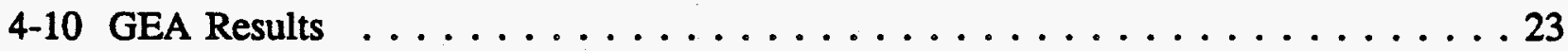

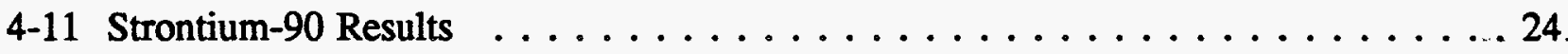

4-12 Total Beta Results . . . . . . . . . . . . . . . . 25

4-13 Plutonium-238, Plutonium-239/240, and Americium-241 Results . . . . . . 26

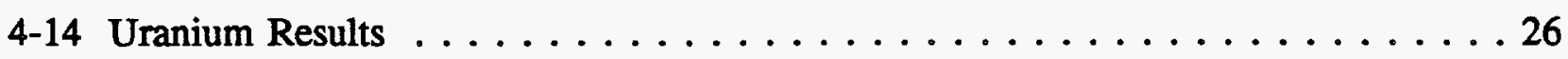

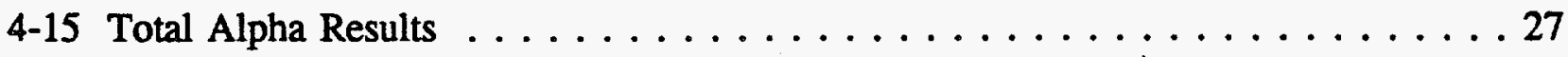

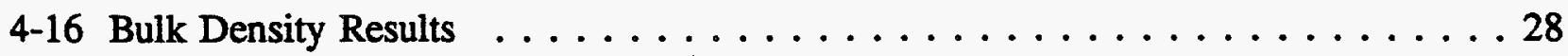




\section{LIST OF TERMS}

AEA

DQO

DSC

GEA

IC

ICP

IS

$\mathrm{KOH}$

PNL

RPD

TC

TGA

TIC

TOC

WHC
Alpha energy analysis

Data Quality Objectives

Differential scanning calorimetry

Gamma energy analysis

Ion chromatography

Inductively coupled plasma atomic emission spectroscopy

Insufficient sample for analysis

Potassium hydroxide

Pacific Northwest Laboratory

Relative percent difference

Total carbon

Thermogravimetric analysis

Total inorganic carbon

Total organic carbon

Westinghouse Hanford Company 
This page intentionally left blank. 


\subsection{INTRODUCTION}

Between November 1992 and March 1993, three core samples were obtained from tank 241-T-107. Analyses were performed on these core samples to support the Ferrocyanide Safety Program and the Hanford Federal Facility Agreement and Consent Order (Ecology et al. 1994) Milestone M-10-00.

This document summarizes and evaluates those analytical results that are pertinent to the Ferrocyanide Safety Issue. This document compares the analytical results with the data requirements for ferrocyanide tanks as documented in Data Requirements of the Ferrocyanide Safery Issue Developed Through the Data Quality Objectives Process (Meacham et al. 1994) and provides an assessment of the safety condition of the tank. Analytes not listed in the Data Quality Objectives (DQO) document (Meacham et al. 1994) or not pertinent to the Ferrocyanide Safety Issue are not discussed in this report. Complete documentation of the analytical results can be found in the data package for the tank 241-T-107 cores (Svancara and Pool 1993). A more complete evaluation of the analytical results and an estimate of the tank inventory will be provided in a forthcoming tank characterization report for tank 241-T-107. 
This page intentionally left blank. 


\subsection{BACKGROUND}

\subsection{TANK 241-T-107 HISTORY}

Single-shell tank 241-T-107, with an operating capacity of 2,006,000 L (530,000 gal), was placed into service in 1944. The tank is on the Ferrocyanide Watch List and is estimated to have contained approximately 5,000 gram moles ferrocyanide $\left[1,060 \mathrm{~kg}\right.$ as $\mathrm{Fe}\left(\mathrm{CN}_{6}{ }_{6}{ }^{4}\right]$ at the end of the ferrocyanide scavenging campaign (Borsheim and Simpson 1991). Tank 241-T-107 is also an assumed leaker. During its process history, it received four main types of waste: first-cycle decontamination waste, tri-butyl phosphate waste (including unconcentrated ferrocyanide scavenged tri-butyl phosphate waste from the U Plant flowsheet used during the scavenging process), cladding waste, and ion-exchange waste. The tank was removed from service in 1976.

\subsection{FERROCYANIDE ISSUE DATA QUALITY OBJECTIVES}

Data requirements for the Ferrocyanide Safety Issue have been developed using the DQO process (Meacham et al. 1994). This process has resulted in the definition of primary decision rules for Ferrocyanide tanks. Two key decision rules were identified to place Ferrocyanide tanks into one of three categories; Safe, Conditionally Safe, and Unsafe (Postma et al. 1994). These decision rules are defined as follows.

- If the fuel concentration average for all homogenized quarter-segment layers ${ }^{1}$ is less than or equal to $8 \mathrm{wt} \%$ as disodium nickel ferrocyanide $\left[\mathrm{Na}_{2} \mathrm{NiFe}(\mathrm{CN})_{6}\right]$ on an energy equivalent basis (i.e., $115 \mathrm{cal} / \mathrm{g}$ of dry material), then the tank is categorized as Safe. Otherwise, the tank is categorized as Conditionally Safe or Unsafe (the moisture and temperature conditions of the tank resolve the difference between these two categories).

- If the fuel concentration in any homogenized quarter-segment layer is greater than $8 w t \%$ and if the $w t \%$ free water ${ }^{2}$ is greater than $4 / 3$ [wt\% fuel ${ }^{3}-8 w t \%$ ], then the

1 Quarter segment $(12 \mathrm{~cm})$ layers apply only to sludge samples. For salt cake samples, analyses will be made on homogenized half-segment $(24 \mathrm{~cm})$ layers. Based on historical records and inference from physical and chemical principles, most of the ferrocyanide should be in the sludge.

${ }^{2}$ Free water is defined as the water removed from a sample by drying at $120^{\circ} \mathrm{C}$ for 18 hours.

$3 \mathrm{Wt} \%$ fuel represents the energy value of the sample based on an equivalent wt\% $\mathrm{Na}_{2} \mathrm{NiFe}(\mathrm{CN})_{6}$. Fuel content is calculated by measuring the exothermic energy of the sample and dividing by the reaction energy of $\mathrm{Na}_{2} \mathrm{NiFe}(\mathrm{CN})_{6}$. 
tank is categorized as Conditionally Safe. Otherwise, the tank is categorized as Unsafe.

Tanks categorized as Safe or Conditionally Safe cannot support a propagating exothermic reaction. The temperature of the waste is a secondary data requirement that is used to support the decision whether a tank is categorized as Conditionally Safe or Unsafe. Temperature is not a core sample data value, but is obtained from instrument tree measurements taken as part of the overall tank surveillance effort.

Furthermore, the DQO process has identified data requirements for the analysis of core samples from Ferrocyanide Watch List tanks. Table 2-1 lists primary and secondary data requirements (those analyses which (1) are necessary to categorize a ferrocyanide tank as Safe, Conditionally Safe, or Unsafe; (2) support the categorization of a Ferrocyanide tank; or (3) are important to the resolution of the Ferrocyanide Safety Issue). Table 2-2 list tertiary data requirements (those analyses necessary for resolving the Ferrocyanide Safety Issue but which do not have the urgency of primary or secondary data requirements).

Table 2-1. Primary and Secondary Data Requirements for Ferrocyanide Tanks.

\begin{tabular}{|c|c|c|c|c|}
\hline Analyte & Analytical method ${ }^{1}$ & Sample $^{2}$ & $\begin{array}{l}\text { Decision }^{3} \\
\text { threshold }\end{array}$ & $\begin{array}{l}\text { Required } \\
\text { analytical } \\
\text { uncertainty }\end{array}$ \\
\hline Total fuel ${ }^{5}$ & $\begin{array}{l}\text { Differential scanning } \\
\text { calorimetry/adiabatic } \\
\text { calorimetry }\end{array}$ & $1 / 4$-Segment & $\begin{array}{l}8 \mathrm{wt} \% \\
(0.48 \mathrm{MJ} / \mathrm{kg} \text { or } \\
115 \mathrm{cal} / \mathrm{g})\end{array}$ & $\leq 10 \%$ \\
\hline Moisture content & Thermogravimetric analysis & 1/4-Segment & $4 / 3$ [Fuel - 8] & $\leq 10 \% 6$ \\
\hline Tank temperature & Thermocouple & $\mathbf{N A}^{7}$ & $90^{\circ} \mathrm{C}$ & $\leq 10 \%$ \\
\hline $\mathrm{Cs}^{137}$ & Gamma energy analysis & $\begin{array}{l}\text { 1/4-Segment } \\
\text { \& liquid }\end{array}$ & $50 \mu \mathrm{Ci} / \mathrm{g}$ & $\leq 10 \%$ \\
\hline $\mathrm{Sr}^{20}$ & Beta radiochemistry & $\begin{array}{l}\text { 1/4-Segment } \\
\text { \& liquid }\end{array}$ & $50 \mu \mathrm{Ci} / \mathrm{g}$ & $\leq 10 \%$ \\
\hline Total cyanide & Direct assay & $1 /$-Segment & $3.9 w t \%$ & $\leq 10 \%$ \\
\hline Total organic carbon & Direct persulfate oxidation & $1 / 4$-Segment & $3 w t \%$ & $\leq 10 \%$ \\
\hline Nickel & Inductively coupled plasma & 1/4-Segment & $1,000 \mu \mathrm{g} / \mathrm{g}$ & $\leq 18 \%$ \\
\hline
\end{tabular}

${ }^{1}$ Other techniques that meet the required uncertainty are also acceptable.

${ }^{2}$ All analyses are conducted on homogenized samples.

${ }^{3}$ Excluding moisture, all decision thresholds reported on a dry basis.

- Values that are less than $25 \%$ of the decision threshold do not require the specified analytical uncertainty.

${ }^{5}$ Calculated on a $\mathrm{Na}_{2} \mathrm{NiFe}(\mathrm{CN})_{6}$ energy equivalent basis.

- Values less than 5 or greater than 35 wt\% water do not require the specified uncertainty.

${ }^{7} \mathrm{NA}=$ Not applicable. 
Table 2-2. Tertiary Data Requirements for Ferrocyanide Tanks.

\begin{tabular}{|c|c|c|c|c|}
\hline Analyte & Analytical method ${ }^{1}$ & Sample $^{2}$ & $\begin{array}{l}\text { Required }^{3} \\
\text { sensitivity }\end{array}$ & $\begin{array}{c}\text { Required } \\
\text { analytical } \\
\text { uncertainty }\end{array}$ \\
\hline $\begin{array}{l}\text { Aluminum, calcium, iron, } \\
\text { phosphorus, sodium }\end{array}$ & Inductively coupled plasma & $\begin{array}{l}\text { 1/4-Segment } \\
\text { \& liquid }\end{array}$ & $500 \mu \mathrm{g} / \mathrm{g}$ & $\leq 25 \%$ \\
\hline $\begin{array}{l}\text { Chloride, fluoride, } \\
\text { nitrate, nitrite, phosphate }\end{array}$ & Ion chromatography & $\begin{array}{l}\text { 1/4-Segment } \\
\text { \& liquid }\end{array}$ & $500 \mu \mathrm{g} / \mathrm{g}$ & $\leq 25 \%$ \\
\hline$\overline{\mathrm{pH}}$ & Ion selective electrode & liquid & $4-12$ & $\pm 0.5^{5}$ \\
\hline Total carbon & Coulometric detection & $1 / 4$-Segment & $1,200 \mu \mathrm{g} / \mathrm{g}$ & $\leq 25 \%$ \\
\hline Total inorganic carbon & Coulometric detection & $1 / 4$-Segment & $1,200 \mu \mathrm{g} / \mathrm{g}$ & $\leq 25 \%$ \\
\hline Total alpha & Proportional counting & $1 / 4$-Segment & $2 \mu \mathrm{Ci} / \mathrm{g}$ & $\leq 18 \%$ \\
\hline Total beta & Proportional counting & $1 / 4$-Segment & $50 \mu \mathrm{Ci} / \mathrm{g}$ & $\leq 18 \%$ \\
\hline Total gamma & $\begin{array}{l}\text { High purity germanium } \\
\text { detector }\end{array}$ & 1/4-Segment & $50 \mu \mathrm{Ci} / \mathrm{g}$ & $\leq 18 \%$ \\
\hline $\mathbf{P u}^{238}$ & $\begin{array}{l}\text { Separation and alpha } \\
\text { spectrometry }\end{array}$ & Composite & $0.1 \mu \mathrm{Ci} / \mathrm{g}$ & $\leq 25 \%$ \\
\hline $\mathrm{Pu}^{239 / 240}$ & $\begin{array}{l}\text { Separation and alpha } \\
\text { spectrometry }\end{array}$ & Composite & $2 \mu \mathrm{Ci} / \mathrm{g}$ & $\leq 25 \%$ \\
\hline $\mathrm{Am}^{241}$ & $\begin{array}{l}\text { Separation and alpha } \\
\text { spectrometry/gamma } \\
\text { energy analysis }\end{array}$ & Composite & $2 \mu \mathrm{Ci} / \mathrm{g}$ & $\leq 25 \%$ \\
\hline $\mathrm{Co}^{60}$ & Gamma energy analysis & Composite & $0.1 \mu \mathrm{Ci} / \mathrm{g}$ & $\leq 25 \%$ \\
\hline$E u^{134 / 135}$ & Gamma energy analysis & Composite & $5 \mu \mathrm{Ci} / \mathrm{g}$ & $\leq 25 \%$ \\
\hline Uranium & $\begin{array}{l}\text { Laser induced kinetic } \\
\text { phosphorescence }\end{array}$ & Composite & $1,000 \mu \mathrm{g} / \mathrm{g}$ & $\leq 25 \%$ \\
\hline Bulk density & Gravimetric & $\begin{array}{l}\text { Composite } \\
\& \text { liquid }\end{array}$ & $\mathrm{NA}^{6}$ & $\leq 10 \%$ \\
\hline Consolidation & Centrifugation & $1 / 4-$ Segment $^{7}$ & NA & $\leq 10 \%$ \\
\hline Particle size & Laser & Composite & $2 \mu \mathrm{m}^{8}$ & $\leq 18 \%$ \\
\hline
\end{tabular}

${ }^{1}$ Other techniques that meet the required uncertainty are also acceptable.

${ }^{2}$ All analyses are conducted on homogenized samples except for consolidation.

${ }^{3}$ Required sensitivity on a dry basis for solid samples.

${ }^{4}$ Values lower than the desired sensitivity do not require this uncertainty.

${ }^{5}$ Values outside this $\mathrm{pH}$ range do not require the specified uncertainty.

${ }^{6} \mathrm{NA}=$ Not applicable.

${ }^{7}$ Consolidation tests must be conducted on samples before homogenization.

${ }^{8}$ An estimate of the total number and mass of particles under $2 \mu \mathrm{m}$ in diameter is required. Determination of particle sizes under $2 \mu \mathrm{m}$ is not necessary. 
This page intentionally left blank. 


\subsection{SAMPLE HANDLING AND ANALYTICAL PROCESS}

\subsection{TANK SAMPLING}

Tank 241-T-107 was push-mode core sampled during a period from November 5, 1992 to March 15, 1993. Initially, two core samples were scheduled for the tank but because of poor sample recovery, a third core sample was taken (Silvers and Noonan 1993). Core 50 was obtained from riser No. 2; Core 51 was obtained from riser No. 5, and Core 52 was obtained from riser No. 3. Each core was composed of four segments. The first segment in Core 50 was resampled because the sampler was left in the tank riser for more than 48 hours, exceeding a requirement that the sample be received at the laboratory within $\mathbf{4 8}$ hours of sampling (Silvers and Noonan 1993). Water was used as the hydrostatic head fluid during sampling; normal paraffin hydrocarbon was not used. The samples were transported to the Westinghouse Hanford Company (WHC) 222-S Laboratory for extrusion and analysis. Selected analyses were also performed at the Pacific Northwest Laboratory's (PNL) Analytical Chemistry Laboratory.

\subsection{CORE SAMPLE DESCRIPTIONS}

The core samples were extruded at the 222-S Laboratory. Table 3-1 provides a listing of the amount of sample recovered and a description of each of the segments. For each core, segments 2 through 4 were expected to be $48-\mathrm{cm}$ (19-in.) long with a total volume of $187 \mathrm{~mL} /$ segment. Because of the tank waste level, Segment 1 was expected to be only $1 / 4$ full (12 cm [ $\sim 5$ in.] of sample). Table 3-2 summarizes the sample recovery for each segment.

Poor recovery resulted in insufficient sample to meet the half-segment analysis criteria that existed at the time of sampling. The subsequent safety criteria document (Postma et al. 1994) and the Ferrocyanide DQO (Meacham et al. 1994) require analysis at the quarter-segment level. Therefore, it may be necessary to resample tank 241-T-107 to definitively categorize the tank. 
Table 3-1. Sample Descriptions.

\begin{tabular}{|c|c|c|c|}
\hline Segment & Core 50 & Core 51 & Core 52 \\
\hline 1 & $\begin{array}{l}\text { Contained } 22.87 \mathrm{~g} \text { of very light to } \\
\text { medium brown solids. Dark stripe } \\
\text { down one side of the extruded solids. } \\
8.75 \mathrm{~g} \text { of opaque brown drainable } \\
\text { liquid }\end{array}$ & $\begin{array}{l}\text { Sampler was } \\
\text { completely empty. }\end{array}$ & $\begin{array}{l}\text { Contained } 28.46 \mathrm{~g} \\
\text { of medium to dark } \\
\text { gray solids. One } \\
\text { side appeared to be } \\
\text { dark gray, the rest } \\
\text { was light gray. No } \\
\text { drainable liquids. }\end{array}$ \\
\hline 1R & $\begin{array}{l}\text { Contained } 25.58 \mathrm{~g} \text { of light brown } \\
\text { solids, homogeneous mixture. } \\
10.89 \mathrm{~g} \text { of opaque brown drainable } \\
\text { liquid. }\end{array}$ & $\mathrm{NA}$ & NA \\
\hline 2 & $\begin{array}{l}\text { Contained } 194.45 \mathrm{~g} \text { of solids. } \\
\text { Sampler was under pressure. Solids } \\
\text { were inhomogeneous and ranged from } \\
\text { a light brown section, similar to } \\
\text { segment } 1 \text { except little darker in } \\
\text { color, to medium brown solids, to a } \\
\text { dark brown section. No drainable } \\
\text { liquid. }\end{array}$ & $\begin{array}{l}\text { Contained } 64.48 \mathrm{~g} \\
\text { of dark brown } \\
\text { solids. } 87.30 \mathrm{~g} \text { of } \\
\text { opaque drainable } \\
\text { liquid; density } \\
1.26 \mathrm{~g} / \mathrm{mL} \text {. }\end{array}$ & $\begin{array}{l}\text { Contained } 111.23 \mathrm{~g} \\
\text { of brown solids. } \\
\text { Solids appeared } \\
\text { wet. }\end{array}$ \\
\hline 3 & $\begin{array}{l}\text { Sample recovered by holding the } \\
\text { sampler vertical and tapping with a } \\
\text { hammer. } 8.53 \mathrm{~g} \text { of dark brown solids } \\
\text { were recovered. The solids were } \\
\text { thick and homogeneous. There was } \\
165 \mathrm{~g} \text { of opaque brown drainable } \\
\text { liquid and with a density of } \\
0.96 \mathrm{~g} / \mathrm{mL} \text {. }\end{array}$ & $\begin{array}{l}\text { Contained } 215.66 \mathrm{~g} \\
\text { of dark brown } \\
\text { solids. Solids } \\
\text { appeared to be } \\
\text { homogeneous. No } \\
\text { drainable liquids. }\end{array}$ & $\begin{array}{l}\text { Contained } 201.41 \mathrm{~g} \\
\text { of solids. Color } \\
\text { ranged from light } \\
\text { brown at bottom to } \\
\text { dark brown at top. } \\
\text { Solids were lumpy. } \\
\text { No drainable } \\
\text { liquids. }\end{array}$ \\
\hline 4 & $\begin{array}{l}\text { A } 1.17 \mathrm{~g} \text { piece of solids that looked } \\
\text { like a flat piece of plastic or a piece } \\
\text { of gum that had been stepped on was } \\
\text { recovered. There was } 120.42 \mathrm{~g} \text { of } \\
\text { opaque brown drainable liquid with a } \\
\text { density } 0.97 \mathrm{~g} / \mathrm{mL} \text {. }\end{array}$ & $\begin{array}{l}\text { Contained } 206.16 \mathrm{~g} \\
\text { of dark brown } \\
\text { solids. Top } 2.5 \mathrm{~cm} \\
(1 \text { in.) and bottom } \\
15 \mathrm{~cm}(6 \text { in. }) \\
\text { appeared to have } \\
\text { more fluids. No } \\
\text { drainable liquids. }\end{array}$ & $\begin{array}{l}\text { Contained } 4.25 \mathrm{~g} \text { of } \\
\text { light brown solids. } \\
117.34 \mathrm{~g} \text { of brown } \\
\text { turbid drainable } \\
\text { liquid; density } \\
1.12 \mathrm{~g} / \mathrm{mL}\end{array}$ \\
\hline
\end{tabular}

NA $=$ Not applicable. 
Table 3-2. Volumetric Sample Recovery.

\begin{tabular}{|c|c|c|c|c|l|}
\hline \multirow{2}{*}{ Core } & \multirow{2}{*}{ Segment } & \% Sample & \multicolumn{2}{|c|}{ Sample obtained } & \multirow{2}{*}{ Comments } \\
\cline { 4 - 5 } & & Recovery & \% Solids & \% Liquids & \\
\hline 50 & 1 & 36 & 72 & 28 & Not used per AE\&R direction \\
\hline 50 & $1 \mathrm{R}$ & 34 & 70 & 30 & Single-segment sample \\
\hline 50 & 2 & 94 & 100 & 0 & Single-segment sample \\
\hline 50 & 3 & 96 & 5 & 95 & Single-segment sample \\
\hline 50 & 4 & 67 & 1 & 99 & Single-segment sample \\
\hline 51 & 1 & 0 & 0 & 0 & No sample \\
\hline 51 & 2 & 64 & 40 & 60 & Single-segment sample \\
\hline 51 & 3 & 100 & 100 & 0 & Two half-segment samples \\
\hline 51 & 4 & 100 & 100 & 0 & Two half-segment samples \\
\hline 52 & 1 & 43 & 100 & 0 & Single-segment sample \\
\hline 52 & 2 & 56 & 100 & 0 & Single-segment sample \\
\hline 52 & 3 & 95 & 100 & 0 & Two half-segment samples \\
\hline 52 & 4 & 60 & 3 & 97 & Single-segment sample \\
\hline
\end{tabular}

AE\&R = Analytical Evaluation and Reporting

\subsection{SAMPLE PREPARATION}

Sample analysis was performed in accordance with the requirements of the following documents.

- Tank Waste Remediation System Tank Waste Characterization Plan (Hill 1992)

- Sampling and Analysis of SST and DST Waste Tanks in Support of TWRS Fiscal Year 1993 Statement of Work (Rich 1993)

- Technical Project Plan for 222-S Laboratory in Support of Tank Waste Remediation System Tank Waste Characterization Plan (WHC-SD-WM-PLN-047, Rev. 0) Statement of Work (WHC-SOW-93-0002) (Winters 1992).

The analyses were performed prior to the development of the Ferrocyanide DQO (Meacham et. al 1994) and the sample breakdown and analysis requirements differed from those of the Ferrocyanide DQO. 
Most of the analyses were performed on core composite samples. Selected analyses were to be performed at the half-segment level. Because of limited sample recoveries, a core composite was not prepared for Core 50 and some segments were not split into half segments for analysis. Samples for Core 50 consisted of segment samples $1 R, 2$, and 3 and a drainable liquid composite. Samples for Core 51 consisted of segment/subsegment samples 2, 3U (upper half of segment 3), 3L (lower half of segment 3), 4U, and 4L; a drainable liquid composite; and a core solids composite. Samples for Core 52 consisted of segment/subsegment samples 1, 2, 3U, and 3L; a drainable liquid composite; and a core solids composite. This sample splitting scheme differs from the Ferrocyanide DQO data requirements, (Meacham et al. 1994) which calls for analysis at the quarter-segment and core composite levels.

Sample matrices were analyzed directly or prepared using water digestion, acid digestion, or potassium hydroxide (KOH) fusion prior to analysis. Acid digestions were performed using a mixture of hydrochloric and nitric acids. The fusions were performed by placing samples in nickel crucibles and fusing them using $\mathrm{KOH}$. Although the fusion method is more likely to dissolve solid components than the acid digestion, it has the disadvantage of diluting the sample more, thereby increasing the detection limit and making trace elements less likely to be detected or analyzed correctly. 


\subsection{DISCUSSION OF ANALYTICAL RESULTS}

This section presents analytical results and compares them to the analytical data requirements of the Ferrocyanide DQO (Meacham et al. 1994). All reported concentrations and results are based on grams of wet sample, unless otherwise specified. When results have been converted to a dry sample basis, the gravimetric weight percent water result for the sample was used to make the conversion. If a gravimetric result was not available, the thermogravimetric analysis (TGA) result was used.

Analytical uncertainties are discussed when the primary or secondary analysis results are at or above $25 \%$ of the decision thresholds. For tertiary analyses, analytical uncertainties are discussed if the analytical results are at or above the required sensitivities.

\subsection{THERMAL ANALYSIS}

\subsubsection{Differential Scanning Calorimetry}

Differential scanning calorimetry (DSC) is used to identify the potential for an exothermic reaction in the waste upon heating. DSC is also used to identify secondary reactions or a change in state that may occur as a result of temperature increases. DSC analysis measures the amount of heat released or absorbed by a sample while it is heated at a constant rate $\left(10^{\circ} \mathrm{C} / \mathrm{min}\right)$. The sample is compared to a reference sample and any temperature difference between the two is recorded as an endothermic or exothermic process. During the heating of a sample, a gas (usually air or nitrogen) is passed over the sample to remove decomposition gases. A graph of the change in heat versus time is plotted. On these particular graphs, an upward peak indicates exothermic behavior while a downward peak indicates endothermic behavior. The computer program on the DSC can calculate the change in heat evolution, whether endothermic or exothermic, by integrating the area under the curve.

DSC was performed on nonhomogenized facies, homogenized segments/subsegments, and drainable liquid composites. Duplicate analyses were performed on most samples, although duplicate analyses were required only when an exothermic reaction was observed. Results of the DSC analysis are provided in Table 4-1. The only sample from tank 241-T-107 to exhibit an exothermic reaction was Core 50 , Segment 4 . In this sample, observation of the extruded sample noted "a flat piece of plastic or a piece of gum that had been stepped on." This item was specifically placed in a vial for DSC/TGA analysis. The sample and duplicate exhibited an exothermic reaction, beginning at about $300^{\circ} \mathrm{C}$, of $1016.4 \mathrm{~J} / \mathrm{g}$ and $1541.2 \mathrm{~J} / \mathrm{g}$ ( $243 \mathrm{cal} / \mathrm{g}$ and $368 \mathrm{cal} / \mathrm{g}$ ), respectively when analyzed with air as a cover gas. DSC measurements with nitrogen as a cover gas were not performed/requested. With the exception of this piece of plastic, which was not representative of the surrounding waste 
matrix, no exothermic reactions were observed in the tank 241-T-107 samples. The DSC results suggest that tank 241-T-107 should be categorized as Safe (i.e., the fuel concentration is less than $115 \mathrm{cal} / \mathrm{g}$ ).

Table 4-1. DSC Results.

\begin{tabular}{|c|c|}
\hline Sample & Results \\
\hline Core 50, Segment $1 \mathrm{R}$, nonhomogenized & No exothermic activity \\
\hline Core 50 , Segment $1 \mathrm{R}$, homogenized & No exothermic activity \\
\hline Core 50, Segment 2, nonhomogenized & No exothermic activity \\
\hline Core 50, Segment 2, homogenized & No exothermic activity \\
\hline Core 50, Segment 3, nonhomogenized & No exothermic activity \\
\hline Core 50, Segment 4 , nonhomogenized & $306 \mathrm{cal} / \mathrm{g}$ beginning at $\sim 300^{\circ} \mathrm{C}$ \\
\hline Core 50, drainable liquid composite & No exothermic activity \\
\hline Core 51, Segment 2, homogenized & No exothermic activity \\
\hline Core 51, Segment 3U, homogenized & No exothermic activity \\
\hline Core 51, Segment 3L, homogenized & No exothermic activity \\
\hline Core 51, Segment 4U, homogenized & No exothermic activity \\
\hline Core 51, Segment $4 \mathrm{~L}$, homogenized & No exothermic activity \\
\hline Core 51, drainable liquid composite & No exothermic activity \\
\hline Core 52 , Segment 1 , homogenized & No exothermic activity \\
\hline Core 52, Segment 2, homogenized & No exothermic activity \\
\hline Core 52, Segment 3U, homogenized & No exothermic activity \\
\hline Core 52 , Segment $3 \mathrm{~L}$, homogenized & No exothermic activity \\
\hline Core 52, Segment 4 , homogenized & No exothermic activity \\
\hline Core 52 , drainable liquid composite & No exothermic activity \\
\hline
\end{tabular}

\subsubsection{Thermogravimetric Analysis And Gravimetric Analysis}

TGA was performed to determine the weight loss of a sample as a function of increasing temperature. TGA was performed on nonhomogenized facies, homogenized segments or subsegments, and drainable liquid composites. The cover gas was air for the TGA measurements. The percent water is calculated by measuring the weight loss at $100{ }^{\circ} \mathrm{C}$. The numbers produced may vary as a result of the small sample size and sample heterogeneity. In Core 50, Segment 4 , an anomalous percent water was noted which was attributed to the fact that the plastic material burned with the air cover gas. The TGA was therefore not measuring the water content of this sample. When the cover gas was changed to nitrogen, no loss in weight was noted. 
Gravimetrically measuring the amount of solids provides more representative measurements of the water/solids content within a sample. The gravimetric method uses a larger sample aliquot than the TGA (about $1 \mathrm{~g}$ versus 10 to $35 \mathrm{mg}$ ), reducing variations caused by sample heterogeneity. The samples are heated in an oven at $102{ }^{\circ} \mathrm{C}$ until the weight measurements do not change, indicating all free water has been removed. All solid composite and homogenized segments or subsegments (except Core 50, Segments 3 and 4 and Core 52, Segment 4) were analyzed in duplicate by this method. Table 4-2 shows the weight percent water results obtained from both the TGA and gravimetric methods. For each method, the relative percent difference (RPD) between samples and duplicates was under $10 \%$ for all samples except for the Core 50, Segment 2, homogenized sample TGA analysis $(R P D=12.79 \%)$. The RPDs between the results for the two methods are shown in Table 4-2.

Table 4-2. Percent Water Results From Thermogravimetric Analysis and Gravimetric Analysis.

\begin{tabular}{|c|c|c|c|}
\hline Sample & $\begin{array}{c}\text { Thermogravimetric } \\
\text { Analysis }\end{array}$ & Gravimetric & RPD (\%) \\
\hline Core 50, Segment 1R, nonhomogenized & $\overline{5.76}$ & $\mathbf{N R}$ & NA \\
\hline Core 50, Segment 1R, homogenized & 26.2 & $\overline{18.0}$ & 37.1 \\
\hline Core 50, Segment 2, nonhomogenized & 29.8 & $\mathbf{N R}$ & $\mathbf{N A}$ \\
\hline Core 50, Segment 2, homogenized & 43.0 & 41.5 & 3.6 \\
\hline Core 50, Segment 3, nonhomogenized & $\overline{43.3}$ & IS & $\overline{\text { NA }}$ \\
\hline Core 50, Segment 4, nonhomogenized & $\begin{array}{c}58.1 \text { w/air } \\
0 \text { w/nitrogen }\end{array}$ & IS & NA \\
\hline Core 51, Segment 2, homogenized & $\overline{59.3}$ & $\overline{60.2}$ & $\overline{1.2}$ \\
\hline Core 51, Segment 3U, homogenized & $\overline{59.6}$ & 55.1 & $\overline{7.9}$ \\
\hline Core 51, Segment 3L, homogenized & 54.2 & 52.9 & $\overline{2.4}$ \\
\hline Core 51, Segment 4U, homogenized & 54.7 & 55.0 & $\overline{0.6}$ \\
\hline Core 51, Segment 4L, homogenized & 53.1 & 49.5 & 7.0 \\
\hline Core 52, Segment 1 , homogenized & 15.2 & 16.7 & 9.4 \\
\hline Core 52, Segment 2, homogenized & 55.5 & 48.5 & $\overline{13.5}$ \\
\hline Core 52, Segment 3U, homogenized & 54.6 & 51.4 & 6.0 \\
\hline Core 52, Segment 3L, homogenized & 52.2 & 53.5 & 2.5 \\
\hline Core 52, Segment 4, homogenized & 53.5 & IS & NA \\
\hline Core 50, drainable liquid composite & $\overline{95.1}$ & 95.6 & 0.5 \\
\hline Core 51 , drainable liquid composite & 73.7 & 75.3 & 2.1 \\
\hline Core 52, drainable liquid composite & 82.9 & 86.5 & 4.3 \\
\hline Core 51, core solids composite & NR & 51.9 & NA \\
\hline Core 52, core solids composite & $\overline{\mathrm{NR}}$ & 47.8 & NA \\
\hline
\end{tabular}

NR = Analysis not required

IS = Insufficient sample for analysis

NA $=$ Not applicable. 


\subsection{CHEMICAL ANALYSIS}

\subsubsection{Cyanide Analysis}

Cyanide analysis was performed on (1) segment/subsegment samples; (2) drainable liquid and solid core composite samples; and (3) the water digestion of the solid core composite samples. Cyanide concentrations were found to be greater in Core 51 samples than in the Core 50 and Core 52 samples. In all samples, the cyanide concentration is considerably lower than the established decision threshold of $3.9 \mathrm{wt} \%(39,000 \mu \mathrm{g} / \mathrm{g}$ dry sample) cyanide. A comparison of the core composites and water digestion results indicated that most of the cyanide is present in water soluble form. Table 4-3 summarizes the cyanide results.

Table 4-3. Cyanide Results.

\begin{tabular}{|c|c|c|c|}
\hline Sample & $\begin{array}{l}\text { Cyanide } \\
(\mu g / g)\end{array}$ & $\begin{array}{c}\text { Cyanide } \\
(\mu \mathrm{g} / \mathrm{g} \text { dry sample) }\end{array}$ & $\begin{array}{c}\text { Ferrocyanide } \\
\text { equivalent }{ }^{1} \\
\text { ( } \mu \mathrm{g} / \mathrm{g} \text { dry sample) }\end{array}$ \\
\hline Core 50, Segment 1R & 48.5 & 59.1 & 80.2 \\
\hline Core 50, Segment 2 & 64.0 & 109 & 148 \\
\hline Core 50, Segment 3 & 42.7 & 75.3 & 102 \\
\hline Core 50, Segment 4 & $\mathbf{I S}^{\mathbf{2}}$ & IS & IS \\
\hline Core 51 , Segment 2 & 95.2 & 239 & 324 \\
\hline Core 51, Segment $3 \mathrm{U}$ & 110 & 245 & 333 \\
\hline Core 51, Segment 3L & 102 & 217 & 295 \\
\hline Core 51, Segment $4 \mathrm{U}$ & 91.5 & 203 & 276 \\
\hline Core 51, Segment 4L & 57.3 & 114 & 155 \\
\hline Core 52, Segment 1 & 31.0 & 37 & 50.2 \\
\hline Core 52, Segment 2 & 61.7 & 120 & 163 \\
\hline Core 52, Segment $3 U$ & 52.1 & 107 & 145 \\
\hline Core 52, Segment 3L & 43.5 & 93.5 & 127 \\
\hline Core 52, Segment 4 & IS & IS & IS \\
\hline Core 50 , drainable liquid composite & $\begin{array}{c}13.4 \\
\mu \mathrm{g} / \mathrm{mL}\end{array}$ & 299 & 406 \\
\hline Core 51 , drainable liquid composite & $\begin{array}{c}152 \\
\mu \mathrm{g} / \mathrm{mL}\end{array}$ & 513 & 697 \\
\hline Core 52, drainable liquids composite & $\begin{array}{c}39.8 \\
\mu \mathrm{g} / \mathrm{mL} \\
\end{array}$ & 266 & 361 \\
\hline Core 51 , core solids composite & 95.8 & 199 & 270 \\
\hline Core 51 , core solids composite, water digest & 91.8 & 191 & 259 \\
\hline Core 52, core solids composite & 56.4 & 108 & 147 \\
\hline Core 52 , core solids composite, water digest & 45.9 & 87.9 & 119 \\
\hline
\end{tabular}

${ }^{1}$ Assumes all cyanide is present as ferrocyanide $\left[\mathrm{Fe}(\mathrm{CN})_{6}{ }^{-1}\right]$.

${ }^{2}$ IS = Insufficient sample for analysis. 


\subsubsection{Carbon Analysis}

The total organic carbon (TOC) and total inorganic carbon (TIC) analyses were performed on the direct subsegment or segment samples and core composite samples using the hot persulfate oxidation method. These analyses were performed by Pacific Northwest Laboratory's Analytical Chemistry Laboratory. The TOC and TIC results were derived independently; total carbon (TC) was calculated by adding the corresponding TOC and TIC values.

The TOC and TIC analyses were performed on the liquid samples (drainable liquid composites and water leach of the core solids composites) using coulometric detection. These analyses were performed at the Westinghouse Hanford Company's 222-S Laboratory.

Results for the hot persulfate oxidation and coulometric detection methods are shown in Tables 4-4 and 4-5. TOC results for all samples are well below the Ferrocyanide DQO-established decision threshold of $3 \mathrm{wt} \%(30,000 \mu \mathrm{g} / \mathrm{g}$ dry sample) carbon. Only the Core 50 drainable liquid composite sample approached the limit. However, this liquid would exist in the tank as interstitial liquid and a layer of waste with such a TOC concentration would not exist in the tank. The TC and TIC results had RPDs below $25 \%$ in almost all cases. The single exception is the Core 52, Segment 3U which had an RPD of $31 \%$ for TC and $41 \%$ for TIC. These high RPDs were attributed to sample inhomogeneity as the sample was observed to contain "unusual hard chunks."

A comparison of the core composite results for the two analytical methods shows a large discrepancy between the results obtained from the hot persulfate oxidation method and the coulometric detection method. Carbon results on the water digestion samples using the coulometric method are two to six times higher than results on the direct samples using the hot persulfate oxidation method. 
Table 4-4. Total Carbon, Total Inorganic Carbon, and Total Organic Carbon Results for Segments and Subsegments.

\begin{tabular}{|l|c|c|c|c|}
\hline \multicolumn{1}{|c|}{ Sample } & $\begin{array}{c}\text { Total } \\
\text { carbon } \\
(\mu \mathrm{g} / \mathrm{g})\end{array}$ & $\begin{array}{c}\text { Total } \\
\text { inorganic } \\
\text { carbon } \\
(\mu \mathrm{g} / \mathrm{g})\end{array}$ & $\begin{array}{c}\text { Total } \\
\text { organic } \\
\text { carbon } \\
(\mu \mathrm{g} / \mathrm{g})\end{array}$ & $\begin{array}{c}\text { Total } \\
\text { organic } \\
\text { carbon } \\
(\mu \mathrm{g} / \mathrm{g} \mathrm{dry} \\
\text { sample })\end{array}$ \\
\hline Core 50, Segment 1R & 2,260 & 1,760 & 505 & 616 \\
\hline Core 50, Segment 2 & 3,690 & 3,040 & 655 & 1,120 \\
\hline Core 50, Segment 3 & IS & IS & IS & IS \\
\hline Core 50, Segment 4 & IS & IS & IS & IS \\
\hline \hline Core 51, Segment 2 & 5,110 & 4,020 & 1,100 & 2,750 \\
\hline Core 51, Segment 3U & 4,420 & 3,150 & 1,270 & 2,820 \\
\hline Core 51, Segment 3L & 3,530 & 2,630 & 905 & 1,920 \\
\hline Core 51, Segment 4U & 3,050 & 2,780 & 265 & 589 \\
\hline Core 51, Segment 4L & 1,930 & 1,670 & 270 & 535 \\
\hline \hline Core 52, Segment 1 & 4,080 & 2,140 & 1,950 & 2,340 \\
\hline Core 52, Segment 2 & 3,930 & 2,960 & 970 & 1,880 \\
\hline Core 52, Segment 3U & 2,040 & 1,350 & 685 & 1,410 \\
\hline Core 52, Segment 3L & 1,760 & 1,490 & 265 & 570 \\
\hline Core 52, Segment 4 & IS & IS & IS & IS \\
\hline
\end{tabular}

IS = Insufficient sample for analysis 
Table 4-5. Total Carbon, Total Inorganic Carbon, and Total Organic Carbon Results for Drainable Liquids and Core Solids Composites.

\begin{tabular}{|l|c|c|c|c|c|}
\hline \multicolumn{1}{|c|}{ Sample } & Method & $\begin{array}{c}\text { Total } \\
\text { carbon } \\
(\mu \mathrm{g} / \mathrm{g})\end{array}$ & $\begin{array}{c}\text { Total } \\
\text { inorganic } \\
\text { carbon } \\
(\mu \mathrm{g} / \mathrm{g})\end{array}$ & $\begin{array}{c}\text { Total } \\
\text { organic } \\
\text { carbon } \\
(\mu \mathrm{g} / \mathrm{g})\end{array}$ & $\begin{array}{c}\text { Total } \\
\text { organic } \\
\text { carbon } \\
(\mu \mathrm{g} / \mathrm{g} \mathrm{dry} \\
\text { sample })\end{array}$ \\
\hline $\begin{array}{l}\text { Core 50, drainable liquid } \\
\text { composite }\end{array}$ & $\begin{array}{c}\text { Coulometric } \\
\text { detection }\end{array}$ & $\begin{array}{c}1,660 \\
\mu \mathrm{g} / \mathrm{mL}\end{array}$ & $512 \mu \mathrm{g} / \mathrm{mL}$ & $\begin{array}{c}1,150 \\
\mu \mathrm{g} / \mathrm{mL}\end{array}$ & 25,600 \\
\hline $\begin{array}{l}\text { Core 51, drainable liquid } \\
\text { composite }\end{array}$ & $\begin{array}{c}\text { Coulometric } \\
\text { detection }\end{array}$ & $\begin{array}{c}5,600 \\
\mu \mathrm{g} / \mathrm{mL}\end{array}$ & $\begin{array}{c}4,540 \\
\mu \mathrm{g} / \mathrm{mL}\end{array}$ & $\begin{array}{c}1,060 \\
\mu \mathrm{g} / \mathrm{mL}\end{array}$ & 3,580 \\
\hline $\begin{array}{l}\text { Core 52, drainable } \\
\text { liquids composite }\end{array}$ & $\begin{array}{c}\text { Coulometric } \\
\text { detection }\end{array}$ & $\begin{array}{c}693 \\
\mu \mathrm{g} / \mathrm{mL}\end{array}$ & $\begin{array}{c}339 \\
\mu \mathrm{g} / \mathrm{mL}\end{array}$ & $\begin{array}{c}354 \\
\mu \mathrm{g} / \mathrm{mL}\end{array}$ & 2,360 \\
\hline \hline $\begin{array}{l}\text { Core 51, core solids } \\
\text { composite, water digest }\end{array}$ & $\begin{array}{c}\text { Coulometric } \\
\text { detection }\end{array}$ & 7,120 & 5,680 & 1,440 & 2,990 \\
\hline $\begin{array}{l}\text { Core 51, core solids } \\
\text { composite, direct }\end{array}$ & $\begin{array}{c}\text { Hot } \\
\text { persulfate } \\
\text { oxidation }\end{array}$ & 2,480 & 2,080 & 400 & 832 \\
\hline $\begin{array}{l}\text { Core 52, core solids } \\
\text { composite, water digest }\end{array}$ & $\begin{array}{c}\text { Coulometric } \\
\text { detection }\end{array}$ & 4,740 & 2,780 & 1,690 & 3,750 \\
\hline $\begin{array}{l}\text { Core 52, core solids } \\
\text { composite, direct }\end{array}$ & $\begin{array}{c}\text { Hot } \\
\text { persulfate } \\
\text { oxidation }\end{array}$ & 1,640 & 1,320 & 320 & 613 \\
\hline
\end{tabular}

\subsubsection{Inductively Coupled Plasma Analysis}

Analysis for metals was performed by inductively coupled plasma atomic emission spectroscopy (ICP). Analyses were performed on drainable liquid composites, core solids composites, and segments or subsegment samples. Preparation methods used on the core solids composites were water digestion, acid digestion, and $\mathrm{KOH}$ fusion. The segment and subsegment samples were prepared by $\mathrm{KOH}$ fusion only. Homogenization check samples (one segment/subsegment per core) were prepared by acid digestion and analyzed using ICP.

ICP results for nickel, aluminum, calcium, iron, phosphorus, and sodium are shown in Tables 4-6 and 4-7. Because nickel crucibles are used in the $\mathrm{KOH}$ fusion, nickel results for the fusion samples are not usable and are not presented. Although nickel concentration data are available only for the acid digested homogenization segments or subsegments, water and acid digested core composites, and drainable liquid composites, all results are below the $1,000 \mu \mathrm{g} / \mathrm{g}$ (dry basis) decision threshold in the Ferrocyanide DQO. 
The DQO does not provide a decision threshold for aluminum, calcium, iron, phosphorus, or sodium but does specify a required analytical sensitivity of $500 \mu \mathrm{g} / \mathrm{g}$ (dry basis). Although the detection limits frequently exceeded this value, the analytical results were generally well above the detection limits. The exception is the drainable liquids analyses, where results were sometimes near the detection limits. In reviewing the aluminum data, most of the samples contain less than $5.0 \times 10^{4} \mu \mathrm{g} / \mathrm{g}$. Only Core 50, Segment 2 and Core 52, Segment 1 have higher concentrations $\left(9.29 \times 10^{4}\right.$ and $2.14 \times 10^{5} \mu \mathrm{g} / \mathrm{g}$, respectively). Calcium results are quite uniform except for the Core 52, Segment 1 samples and one of the four core composite results. This anomalous calcium concentration could be attributed to glove powder used by personnel in the laboratory. Iron concentrations appear to be fairly consistent throughout the tank. Phosphorus results show widely differing phosphorus content in different areas of the tank. Sodium results have matched duplicate pairs but appear to vary by location in the tank. Composite results for sodium are generally higher than segment results.

Table 4-6. ICP Results for Nickel.

\begin{tabular}{|l|c|c|}
\hline \multicolumn{1}{|c|}{ Sample } & $\begin{array}{c}\text { Nickel } \\
(\mu \mathrm{g} / \mathrm{g})\end{array}$ & $\begin{array}{c}\text { Nickel } \\
(\mu \mathrm{g} / \mathrm{g} \text { dry sample })\end{array}$ \\
\hline $\begin{array}{l}\text { Core 50, Segment 2, acid } \\
\text { digestion }\end{array}$ & 148 & 252 \\
\hline $\begin{array}{l}\text { Core 51, Segment 3L, acid } \\
\text { digestion }\end{array}$ & 216 & 458 \\
\hline $\begin{array}{l}\text { Core 52, Segment 3L, acid } \\
\text { digestion }\end{array}$ & 35.2 & 75.6 \\
\hline \hline $\begin{array}{l}\text { Core 50, drainable liquid } \\
\text { composite }\end{array}$ & $\begin{array}{c}1.77 \\
\mu \mathrm{g} / \mathrm{mL}\end{array}$ & 39.4 \\
\hline $\begin{array}{l}\text { Core 51, drainable liquid } \\
\text { composite }\end{array}$ & $\begin{array}{c}16.0 \\
\mu \mathrm{g} / \mathrm{mL}\end{array}$ & 54.0 \\
\hline $\begin{array}{l}\text { Core 52, drainable liquid } \\
\text { composite }\end{array}$ & $\begin{array}{c}2.79 \\
\mu \mathrm{g} / \mathrm{mL}\end{array}$ & 18.6 \\
\hline \hline $\begin{array}{l}\text { Core 51, core solids } \\
\text { composite, water digestion }\end{array}$ & 4.49 & 9.33 \\
\hline $\begin{array}{l}\text { Core 51, core solids } \\
\text { composite, acid digestion }\end{array}$ & 304 & 632 \\
\hline $\begin{array}{l}\text { Core 52, core solids } \\
\text { composite, water digestion }\end{array}$ & $<13.2$ & $<25.3$ \\
\hline $\begin{array}{l}\text { Core 52, core solids } \\
\text { composite, acid digestion }\end{array}$ & 279 & 534 \\
\hline
\end{tabular}


Table 4-7. ICP Results for Aluminum, Calcium, Iron, Sodium, and Phosphorus.

\begin{tabular}{|l|c|c|c|c|c|}
\hline \multicolumn{1}{|c|}{ Sample } & $\begin{array}{c}\text { Aluminum } \\
(\mu \mathrm{g} / \mathrm{g})\end{array}$ & $\begin{array}{c}\text { Calcium } \\
(\mu \mathrm{g} / \mathrm{g})\end{array}$ & $\begin{array}{c}\text { Iron } \\
(\mu \mathrm{g} / \mathrm{g})\end{array}$ & $\begin{array}{c}\text { Sodium } \\
(\mu \mathrm{g} / \mathrm{g})\end{array}$ & $\begin{array}{c}\text { Phosphorus } \\
(\mu \mathrm{g} / \mathrm{g})\end{array}$ \\
\hline $\begin{array}{l}\text { Core 50, Segment 1R, } \\
\text { fusion }\end{array}$ & 9,810 & 1,050 & 19,000 & 127,000 & 30,600 \\
\hline $\begin{array}{l}\text { Core 50, Segment 2, } \\
\text { fusion }\end{array}$ & 92,900 & 822 & 20,400 & 55,200 & 3,840 \\
\hline $\begin{array}{l}\text { Core 50, Segment 2, } \\
\text { acid digestion }\end{array}$ & 95,600 & 900 & 24,100 & 71,300 & 5,240 \\
\hline $\begin{array}{l}\text { Core 50, Segment 3, } \\
\text { fusion }\end{array}$ & 20,700 & 1,100 & 23,800 & 123,000 & 42,700 \\
\hline $\begin{array}{l}\text { Core 50, Segment 4, } \\
\text { fusion }\end{array}$ & IS & IS & IS & IS & IS \\
\hline $\begin{array}{l}\text { Core 51, Segment 2, } \\
\text { fusion }\end{array}$ & 12,000 & 2,090 & 36,700 & 71,100 & 5,330 \\
\hline $\begin{array}{l}\text { Core 51, Segment 3U, } \\
\text { fusion }\end{array}$ & 1,240 & 961 & 28,500 & 108,000 & 25,100 \\
\hline $\begin{array}{l}\text { Core 51, Segment 3L, } \\
\text { fusion }\end{array}$ & 688 & 989 & 34,300 & 77,900 & 7,610 \\
\hline $\begin{array}{l}\text { Core 51, Segment 3L, } \\
\text { acid digestion }\end{array}$ & 267 & 848 & 40,700 & 89,400 & 9,320 \\
\hline $\begin{array}{l}\text { Core 51, Segment 4U, } \\
\text { fusion }\end{array}$ & 2,270 & 1,430 & 35,100 & 82,500 & 9,700 \\
\hline $\begin{array}{l}\text { Core 51, Segment 4L, } \\
\text { fusion }\end{array}$ & 9,210 & 2,440 & 19,700 & 122,000 & 32,400 \\
\hline $\begin{array}{l}\text { Core 52, Segment 1, } \\
\text { fusion }\end{array}$ & 214,000 & 10,900 & 40,500 & 27,300 & $<226$ \\
\hline $\begin{array}{l}\text { Core 52, Segment 2, } \\
\text { fusion }\end{array}$ & 43,000 & 771 & 21,000 & 105,000 & 25,600 \\
\hline $\begin{array}{l}\text { Core 52, Segment 3U, } \\
\text { fusion }\end{array}$ & 8,170 & 800 & 23,400 & 131,000 & 36,900 \\
\hline $\begin{array}{l}\text { Core 52, Segment 3L, } \\
\text { fusion }\end{array}$ & 15,400 & 422 & 19,000 & 107,000 & 26,000 \\
\hline $\begin{array}{l}\text { Core 52, Segment 3L, } \\
\text { acid digestion }\end{array}$ & 15,800 & 499 & 20,200 & 113,000 & 26,600 \\
\hline $\begin{array}{l}\text { Core 52, Segment 4, } \\
\text { fusion }\end{array}$ & IS & IS & IS & $\cdot$ IS & IS \\
\hline
\end{tabular}


Table 4-7. ICP Results for Aluminum, Calcium, Iron, Sodium, and Phosphorus.

\begin{tabular}{|l|c|c|c|c|c|}
\hline \multicolumn{1}{|c|}{ Sample } & $\begin{array}{c}\text { Aluminum } \\
(\mu \mathrm{g} / \mathrm{g})\end{array}$ & $\begin{array}{c}\text { Calcium } \\
(\mu \mathrm{g} / \mathrm{g})\end{array}$ & $\begin{array}{c}\text { Iron } \\
(\mu \mathrm{g} / \mathrm{g})\end{array}$ & $\begin{array}{c}\text { Sodium } \\
(\mu \mathrm{g} / \mathrm{g})\end{array}$ & $\begin{array}{c}\text { Phosphorus } \\
(\mu \mathrm{g} / \mathrm{g})\end{array}$ \\
\hline \hline $\begin{array}{l}\text { Core 50, drainable } \\
\text { liquid composite }\end{array}$ & $\begin{array}{c}4.25 \\
\mu \mathrm{g} / \mathrm{mL}\end{array}$ & $\begin{array}{c}4.28 \\
\mu \mathrm{g} / \mathrm{mL}\end{array}$ & $\begin{array}{c}5.75 \\
\mu \mathrm{g} / \mathrm{mL}\end{array}$ & $\begin{array}{c}14,600 \\
\mu \mathrm{g} / \mathrm{mL}\end{array}$ & $\begin{array}{c}790 \\
\mu \mathrm{g} / \mathrm{mL}\end{array}$ \\
\hline $\begin{array}{l}\text { Core 51, drainable } \\
\text { liquid composite }\end{array}$ & $\begin{array}{c}11.5 \\
\mu \mathrm{g} / \mathrm{mL}\end{array}$ & $\begin{array}{c}4.97 \\
\mu \mathrm{g} / \mathrm{mL}\end{array}$ & $\begin{array}{c}4.8 \\
\mu \mathrm{g} / \mathrm{mL}\end{array}$ & $\begin{array}{c}95,500 \\
\mu \mathrm{g} / \mathrm{mL}\end{array}$ & $\begin{array}{c}2,020 \\
\mu \mathrm{g} / \mathrm{mL}\end{array}$ \\
\hline $\begin{array}{l}\text { Core 52, drainable } \\
\text { liquid composite }\end{array}$ & $\begin{array}{c}47.8 \\
\mu \mathrm{g} / \mathrm{mL}\end{array}$ & $\begin{array}{c}3.94 \\
\mu \mathrm{g} / \mathrm{mL}\end{array}$ & $\begin{array}{c}19.0 \\
\mu \mathrm{g} / \mathrm{mL}\end{array}$ & $\begin{array}{c}51,900 \\
\mu \mathrm{g} / \mathrm{mL}\end{array}$ & $\begin{array}{c}2,590 \\
\mu \mathrm{g} / \mathrm{mL}\end{array}$ \\
\hline $\begin{array}{l}\text { Core 51, core solids } \\
\text { composite, water } \\
\text { digestion }\end{array}$ & 485 & 476 & 272 & 134,000 & 30,300 \\
\hline $\begin{array}{l}\text { Core 51, core solids } \\
\text { composite, acid } \\
\text { digestion }\end{array}$ & 4,140 & 853 & 33,200 & 137,000 & 29,600 \\
\hline $\begin{array}{l}\text { Core 51, core solids } \\
\text { composite, fusion }\end{array}$ & 5,730 & 779 & 26,500 & 123,000 & 32,900 \\
\hline $\begin{array}{l}\text { Core 52, core solids } \\
\text { composite, water } \\
\text { digestion }\end{array}$ & 816 & 65.5 & 439 & 81,800 & 17,100 \\
\hline $\begin{array}{l}\text { Core 52, core solids } \\
\text { composite, acid } \\
\text { digestion }\end{array}$ & 24,600 & 592 & 29,800 & 124,000 & 30,400 \\
\hline $\begin{array}{l}\text { Core 52, core solids } \\
\text { composite, fusion }\end{array}$ & 26,900 & 742 & 31,900 & 112,000 & 31,300 \\
\hline
\end{tabular}

IS = Insufficient sample for analysis

\subsubsection{Anion Analysis}

Chloride, fluoride, nitrate, nitrite, and phosphate analyses was performed using ion chromatography (IC). Because the nitrite results from IC analysis are considered estimates, nitrite analyses were also performed using spectrophotometric methods. These analyses were performed on the drainable liquid composites and on the water digestions of the solid core composites.

Results of the analyses are shown in Table 4-8. The IC revealed relatively high concentrations of all anions in the core samples except chloride. A comparison of the nitrite results from both IC the spectrophotometry show good agreement between the two methods. With the exception of the Core 51 drainable liquid composite, RPDs between the two 
methods are less than $10 \%$. The phosphate results compare quite well with the ICP phosphorus results. If it is assumed that all the phosphorus exists as phosphate, the RPDs between the two methods is less than $5 \%$ for the drainable liquids and the Core 51 core solids composite samples. There is a discrepancy between the IC and ICP results for the Core 52 core solids composite samples; the phosphate results are more than twice as high as the phosphorus. The detection limits did not always meet the DQO's required sensitivity of $500 \mu \mathrm{g} / \mathrm{g}$ dry sample, but IC results for the water digestion samples and all the spectrophotometric nitrite results were well above the detection limits. IC results for the drainable liquids were often near the detection limits.

Table 4-8. Anion Results.

\begin{tabular}{|l|c|c|c|c|c|c|}
\hline \multicolumn{1}{|c|}{ Sample } & $\mathrm{F}^{-}(\mu \mathrm{g} / \mathrm{g})$ & $\begin{array}{c}\mathrm{Cl}^{-} \\
(\mu \mathrm{g} / \mathrm{g})\end{array}$ & $\begin{array}{c}\mathrm{PO}_{4}^{-3} \\
(\mu \mathrm{g} / \mathrm{g})\end{array}$ & $\begin{array}{c}\mathrm{NO}_{3}^{-} \\
(\mu \mathrm{g} / \mathrm{g})\end{array}$ & $\begin{array}{c}\mathrm{NO}_{2}^{-} \\
(\mathrm{IC}) \\
(\mu \mathrm{g} / \mathrm{g})\end{array}$ & $\begin{array}{c}\mathrm{NO}_{2}^{-} \\
(\mathrm{spec}) \\
(\mu \mathrm{g} / \mathrm{g})\end{array}$ \\
\hline $\begin{array}{l}\text { Core } 50, \text { drainable } \\
\text { liquid composite }\end{array}$ & $\begin{array}{c}174 \\
\mu \mathrm{g} / \mathrm{mL}\end{array}$ & $\begin{array}{c}196 \\
\mu \mathrm{g} / \mathrm{mL}\end{array}$ & $\begin{array}{c}2,400 \\
\mu \mathrm{g} / \mathrm{mL}\end{array}$ & $\begin{array}{c}21,200 \\
\mu \mathrm{g} / \mathrm{mL}\end{array}$ & $\begin{array}{c}2,580 \\
\mu \mathrm{g} / \mathrm{mL}\end{array}$ & $\begin{array}{c}2,730 \\
\mu \mathrm{g} / \mathrm{mL}\end{array}$ \\
\hline $\begin{array}{l}\text { Core } 51, \text { drainable } \\
\text { liquid composite }\end{array}$ & $\begin{array}{c}825 \\
\mu \mathrm{g} / \mathrm{mL}\end{array}$ & $\begin{array}{c}1,340 \\
\mu \mathrm{g} / \mathrm{mL}\end{array}$ & $\begin{array}{c}6,240 \\
\mu \mathrm{g} / \mathrm{mL}\end{array}$ & $\begin{array}{c}134,000 \\
\mu \mathrm{g} / \mathrm{mL}\end{array}$ & $\begin{array}{c}27,600 \\
\mu \mathrm{g} / \mathrm{mL}\end{array}$ & $\begin{array}{c}12,500 \\
\mu \mathrm{g} / \mathrm{mL}\end{array}$ \\
\hline $\begin{array}{l}\text { Core 52, drainable } \\
\text { liquid composite }\end{array}$ & $\begin{array}{c}673 \\
\mu \mathrm{g} / \mathrm{mL}\end{array}$ & $\begin{array}{c}860 \\
\mu \mathrm{g} / \mathrm{mL}\end{array}$ & $\begin{array}{c}7,630 \\
\mu \mathrm{g} / \mathrm{mL}\end{array}$ & $\begin{array}{c}100,000 \\
\mu \mathrm{g} / \mathrm{mL}\end{array}$ & $\begin{array}{c}8,060 \\
\mu \mathrm{g} / \mathrm{mL}\end{array}$ & $\begin{array}{c}7,420 \\
\mu \mathrm{g} / \mathrm{mL}\end{array}$ \\
\hline \hline $\begin{array}{l}\text { Core 51, core } \\
\text { solids composite, } \\
\text { water digestion }\end{array}$ & 9,200 & 682 & 94,500 & 92,800 & 15,300 & 14,200 \\
\hline $\begin{array}{l}\text { Core 52, core } \\
\text { solids composite, } \\
\text { water digestion }\end{array}$ & 13,700 & 412 & 133,000 & 58,000 & 8,360 & 7,980 \\
\hline
\end{tabular}

\subsection{5 pH Analysis}

Analyses for $\mathrm{pH}$ were performed on the direct segments/subsegments, core composites, and drainable liquid composite samples. Results are given in Table 4-9. The pH results ranged from 9.6 to 11.8. Duplicate analyses were run for fourteen of the samples; sample and duplicate results differed by no more than $0.1 \mathrm{pH}$ unit. 
Table 4-9. pH Results.

\begin{tabular}{|l|c|}
\hline \multicolumn{1}{|c|}{ Sample } & $\mathrm{pH}$ \\
\hline Core 50, Segment 1R & 10.3 \\
\hline Core 50, Segment 2 & 11.2 \\
\hline Core 50, Segment 3 & 11.4 \\
\hline Core 50, Segment 4 & $\mathrm{IS}$ \\
\hline \hline Core 51, Segment 2 & 10.5 \\
\hline Core 51, Segment 3U & 11.4 \\
\hline Core 51, Segment 3L & 11.4 \\
\hline Core 51, Segment 4U & 11.2 \\
\hline Core 51, Segment 4L & 11.6 \\
\hline \hline Core 52, Segment 1 & 10.5 \\
\hline Core 52, Segment 2 & 11.4 \\
\hline Core 52, Segment 3U & 11.8 \\
\hline Core 52, Segment 3L & 10.9 \\
\hline Core 52, Segment 4 & IS \\
\hline \hline Core 50 drainable liquid composite & 9.6 \\
\hline Core 51, drainable liquid composite & 10.7 \\
\hline Core 52, drainable liquid composite & 10.3 \\
\hline \hline Core 51, core solids composite & 11.6 \\
\hline Core 52, core solids composite & 11.4 \\
\hline
\end{tabular}

IS = Insufficient sample for analysis

\subsection{RADIOCHEMICAL ANALYSIS}

\subsubsection{Gamma Energy Analysis}

Gamma energy analysis (GEA) was performed on the drainable liquid composites, the fusion and water digestions of the solid core composites, and the fusion of the segment/subsegment samples. Cesium-137, $\mathrm{Co}^{60}, \mathrm{Eu}^{154}$, and $\mathrm{Eu}^{155}$ results are shown in Table 4-10. Americium-241 results are presented and discussed in Section 4.3.3, along with the alpha energy analysis (AEA) results for $\mathrm{Am}^{241}$. With one exception, all $\mathrm{Cs}^{137}$ results were below 
the decision threshold of $200 \mu \mathrm{Ci} / \mathrm{g}$ dry sample. Segment 2 of Core 51 had a $\mathrm{Cs}^{137}$ concentration of $99.9 \mu \mathrm{Ci} / \mathrm{g}$ ( $251 \mu \mathrm{g} / \mathrm{g}$ dry sample), five to ten times higher than any other sample. A confirmation analysis was performed and the results proved similar to previous numbers. The Core 51 solids composite results were not correspondingly high. The discrepancy may be due to sample inhomogeneity.

Cobalt-60, $\mathrm{Eu}^{154}$, and $\mathrm{Eu}^{155}$ results were generally below detection limits. The detection limits (below $0.2 \mu \mathrm{Ci} / \mathrm{g}$ ) and the results were well below the DQO's required sensitivity.

Table 4-10. GEA Results.

\begin{tabular}{|c|c|c|c|c|c|}
\hline Sample & $\begin{array}{c}\mathrm{Co}^{60} \\
(\mu \mathrm{Ci} / \mathrm{g})\end{array}$ & $\begin{array}{c}\mathrm{Eu}^{\mathrm{IS}} \\
(\mu \mathrm{Ci} / \mathrm{g})\end{array}$ & $\begin{array}{c}\mathrm{Eu}^{135} \\
(\mu \mathrm{Ci} / \mathrm{g})\end{array}$ & $\mathrm{Cs}^{137}(\mu \mathrm{Ci} / \mathrm{g})$ & $\begin{array}{c}\mathrm{Cs}^{137} \\
(\mu \mathrm{Ci} / \mathrm{g} \text { dry } \\
\text { sample })\end{array}$ \\
\hline Core 50, Segment 1R & $<6.8 \times 10^{-3}$ & 0.0885 & 0.0859 & 7.03 & 8.6 \\
\hline Core 50, Segment 2 & $<1.27 \times 10^{-2}$ & $<3.14 \times 10^{-2}$ & $<7.01 \times 10^{-2}$ & 11.8 & 20.2 \\
\hline Core 50, Segment 3 & $<5.94 \times 10^{-3}$ & $<1.78 \times 10^{-2}$ & $<4.11 \times 10^{-2}$ & 6.04 & 10.7 \\
\hline Core 50, Segment 4 & IS & IS & IS & IS & IS \\
\hline Core 51, Segment 2 & $<1.05 \times 10^{-2}$ & 0.314 & $<1.41 \times 10^{-1}$ & 99.9 & 251 \\
\hline Core 51, Segment 3U & $<3.93 \times 10^{-3}$ & $<2.11 \times 10^{-2}$ & $<8.60 \times 10^{-2}$ & 15.3 & 34.1 \\
\hline Core 51, Segment 3L & 0.0376 & 0.0437 & $<9.49 \times 10^{-2}$ & 17.1 & 36.3 \\
\hline Core 51, Segment 4U & 0.0264 & $<2.52 \times 10^{-2}$ & $<9.49 \times 10^{-2}$ & 17.9 & 39.8 \\
\hline Core 51, Segment 4L & $<8.92 \times 10^{-3}$ & $<2.12 \times 10^{-2}$ & $<5.35 \times 10^{-2}$ & 13.6 & 26.9 \\
\hline Core 52, Segment 1 & $<6.39 \times 10^{-3}$ & 1.08 & 0.919 & 10.9 & 13.1 \\
\hline Core 52, Segment 2 & $<2.51 \times 10^{-2}$ & $<7.37 \times 10^{-2}$ & $<8.27 \times 10^{-2}$ & 10.3 & 20.0 \\
\hline Core 52, Segment 3U & $<2.13 \times 10^{-2}$ & $<7.74 \times 10^{-2}$ & $<8.11 \times 10^{-2}$ & 7.83 & 16.1 \\
\hline Core 52, Segment 3L & $<2.54 \times 10^{-2}$ & $<6.74 \times 10^{-2}$ & $<6.86 \times 10^{-2}$ & 10.6 & 22.8 \\
\hline Core 52, Segment 4 & IS & IS & IS & IS & IS \\
\hline $\begin{array}{l}\text { Core } 50 \text {, drainable liquid } \\
\text { composite }\end{array}$ & $\begin{array}{c}<5.28 \times 10^{-4} \\
\mu \mathrm{Ci} / \mathrm{mL}\end{array}$ & $\begin{array}{c}<1.44 \times 10^{-3} \\
\mu \mathrm{Ci} / \mathrm{mL}\end{array}$ & $\begin{array}{l}<3.14 \times 10^{-3} \\
\mu \mathrm{Ci} / \mathrm{mL}\end{array}$ & $\begin{array}{c}1.72 \\
\mu \mathrm{Ci} / \mathrm{mL}\end{array}$ & 38.3 \\
\hline $\begin{array}{l}\text { Core } 51 \text {, drainable liquid } \\
\text { composite }\end{array}$ & $\begin{array}{c}<1.35 \times 10^{-3} \\
\mu \mathrm{Ci} / \mathrm{mL}\end{array}$ & $\begin{array}{c}<4.23 \times 10^{-3} \\
\mu \mathrm{Ci} / \mathrm{mL}\end{array}$ & $\begin{array}{c}<1.50 \times 10^{-2} \\
\mu \mathrm{Ci} / \mathrm{mL}\end{array}$ & $\begin{array}{c}18.4 \\
\mu \mathrm{Ci} / \mathrm{mL}\end{array}$ & 62.1 \\
\hline $\begin{array}{l}\text { Core } 52 \text {, drainable liquid } \\
\text { composite }\end{array}$ & $\begin{array}{l}<1.24 \times 10^{-4} \\
\mu \mathrm{Ci} / \mathrm{mL}\end{array}$ & $\begin{array}{c}<5.50 \times 10^{-4} \\
\mu \mathrm{Ci} / \mathrm{mL}\end{array}$ & $\begin{array}{c}<2.65 \times 10^{-3} \\
\mu \mathrm{Ci} / \mathrm{mL}\end{array}$ & $\begin{array}{c}5.23 \\
\mu \mathrm{Ci} / \mathrm{mL}\end{array}$ & 34.9 \\
\hline $\begin{array}{l}\text { Core } 51 \text {, core solids } \\
\text { composite, water digestion }\end{array}$ & $<1.45 \times 10^{-3}$ & $<3.91 \times 10^{-3}$ & $<1.25 \times 10^{-2}$ & 12.0 & 24.9 \\
\hline $\begin{array}{l}\text { Core } 51 \text {, core solids } \\
\text { composite, fusion }\end{array}$ & $<2.39 \times 10^{-2}$ & $<6.44 \times 10^{-2}$ & $<9.21 \times 10^{-2}$ & 13.9 & 28.9 \\
\hline $\begin{array}{l}\text { Core } 52 \text {, core solids } \\
\text { composite, water digestion }\end{array}$ & $<2.08 \times 10^{-3}$ & $<5.82 \times 10^{-3}$ & $<1.51 \times 10^{-2}$ & 9.49 & 18.2 \\
\hline $\begin{array}{l}\text { Core } 52 \text {, core solids } \\
\text { composite, fusion }\end{array}$ & $<6.58 \times 10^{-3}$ & 0.0688 & $<4.07 \times 10^{-2}$ & 10.6 & 20.3 \\
\hline
\end{tabular}

IS = Insufficient sample for analysis 


\subsubsection{Strontium-90 Analysis}

Strontium-90 analyses were performed on drainable liquid composites and fusion preparations of solid core composites and segment/subsegment samples. Results are presented in Table 4-11. RPDs for twelve of the seventeen sets of analyses were below $10 \%$. RPDs that exceeded the $10 \%$ criterion ranged from $11 \%$ to $28 \%$. Strontium results vary widely, but are generally near or above the $200 \mu \mathrm{Ci} / \mathrm{g}$ dry sample decision threshold. The highest results (up to $504.4 \mu \mathrm{Ci} / \mathrm{g}$ dry sample) are seen in Core 51 .

Table 4-11. Strontium-90 Results.

\begin{tabular}{|l|c|c|}
\hline \multicolumn{1}{|c|}{ Sample } & $\begin{array}{c}\mathrm{Sr}^{90} \\
(\mu \mathrm{Ci} / \mathrm{g})\end{array}$ & $\begin{array}{c}\mathrm{Sr}^{80} \\
(\mu \mathrm{Ci} / \mathrm{g} \text { dry sample })\end{array}$ \\
\hline Core 50, Segment 1R & 31.6 & 38.5 \\
\hline Core 50, Segment 2 & 153 & 262 \\
\hline Core 50, Segment 3 & 125 & 221 \\
\hline Core 50, Segment 4 & $\mathrm{IS}$ & $\mathrm{IS}$ \\
\hline \hline Core 51, Segment 2 & 201 & 475 \\
\hline Core 51, Segment 3U & 242 & 448 \\
\hline Core 51, Segment 3L & 227 & 514 \\
\hline Core 51, Segment 4U & 27.5 & 504 \\
\hline Core 51, Segment 4L & 165 & 54.5 \\
\hline \hline Core 52, Segment 1 & 88.0 & 198 \\
\hline Core 52, Segment 2 & 95.9 & 171 \\
\hline Core 52, Segment 3U & 18.1 & 197 \\
\hline Core 52, Segment 3L & $\mathrm{IS}$ & 38.9 \\
\hline Core 52, Segment 4 & 84.1 & $\mathrm{IS}$ \\
\hline \hline $\begin{array}{l}\text { Core 50, drainable liquid } \\
\text { composite }\end{array}$ & $0.0108 \cdot \mu \mathrm{Ci} / \mathrm{mL}$ & 0.241 \\
\hline $\begin{array}{l}\text { Core 51, drainable liquid } \\
\text { composite }\end{array}$ & $0.123 \mu \mathrm{Ci} / \mathrm{mL}$ & 0.415 \\
\hline $\begin{array}{l}\text { Core 52, drainable liquid } \\
\text { composite }\end{array}$ & $0.0449 \mu \mathrm{Ci} / \mathrm{mL}$ & 0.300 \\
\hline \hline $\begin{array}{l}\text { Core 51, core solids } \\
\text { composite }\end{array}$ & 132 & 274 \\
\hline $\begin{array}{l}\text { Core 52, core solids } \\
\text { composite }\end{array}$ & 161 \\
\hline
\end{tabular}

IS = Insufficient sample for analysis 


\subsubsection{Total Beta Analysis}

Total beta analysis was performed on the fusion and water digestions of the core solids composite samples and on the drainable liquid composites. Total beta results are shown in Table 4-12. Total beta results from the 222-S Laboratory are based on the efficiency of the detector for $\mathrm{Co}^{60}$. Beta emissions from other isotopes have lower or higher efficiencies depending on their energies. Because $\mathrm{Co}^{60}$ is lower in energy than the isotopes usually present in Hanford Site wastes, the total beta results are usually biased high. Cesium-137 and $\mathrm{Sr}^{90}$ are the major beta emitters in the tank waste. Total beta results were compared to the sum of the $\mathrm{Cs}^{137}$ and $\mathrm{Sr}^{90}$ results. Total beta results were higher with the ratio of total beta to cesium and strontium ranging from about 1.3 for drainable liquid and water digestion samples to about 2.7 for fusion samples. The RPDs for the total beta results were $14 \%$ or lower.

Table 4-12. Total Beta Results.

\begin{tabular}{|l|c|}
\hline \multicolumn{1}{|c|}{ Sample } & $\begin{array}{c}\text { Total beta } \\
(\mu \mathrm{Ci} / \mathrm{g})\end{array}$ \\
\hline $\begin{array}{l}\text { Core 50, drainable liquid } \\
\text { composite }\end{array}$ & $\begin{array}{c}2.5 \\
\mathrm{Ci} / \mathrm{mL}\end{array}$ \\
\hline $\begin{array}{l}\text { Core } 51, \text { drainable liquid } \\
\text { composite }\end{array}$ & $\begin{array}{c}25.1 \\
\mu \mathrm{Ci} / \mathrm{mL}\end{array}$ \\
\hline $\begin{array}{l}\text { Core 52, drainable liquid } \\
\text { composite }\end{array}$ & $\begin{array}{c}7.55 \\
\mu \mathrm{Ci} / \mathrm{mL}\end{array}$ \\
\hline \hline $\begin{array}{l}\text { Core 51, core solids } \\
\text { composite, water digestion }\end{array}$ & 16.5 \\
\hline $\begin{array}{l}\text { Core 51, core solids } \\
\text { composite, fusion }\end{array}$ & 404 \\
\hline $\begin{array}{l}\text { Core 52, core solids } \\
\text { composite, water digestion }\end{array}$ & 10.3 \\
\hline $\begin{array}{l}\text { Core 52, core solids } \\
\text { composite, fusion }\end{array}$ & 257 \\
\hline
\end{tabular}

\subsubsection{Alpha Energy Analysis}

AEA was performed on fusion preparations for one subsegment and core composites. Drainable liquid composites were also analyzed by AEA. AEA results for $\mathrm{Pu}^{238}, \mathrm{Pu}^{239 / 240}$, and $\mathrm{Am}^{241}$ are shown in Table 4-13. Americium-241 results from GEA analysis are also shown for comparison. All the results are below the required sensitivity of $50 \mu \mathrm{Ci} / \mathrm{g}$ (dry sample). AEA detection limits were below $0.02 \mu \mathrm{Ci} / \mathrm{g}$ for $\mathrm{Pu}^{238}, 10^{4} \mu \mathrm{Ci} / \mathrm{g}$ for $\mathrm{Pu}^{2392240}$ and $\mathrm{Am}^{241}$. Americium-241 detection limits were below $0.1 \mu \mathrm{Ci} / \mathrm{g}$ for the GEA. 
Table 4-13. Plutonium ${ }^{238}$, Plutonium ${ }^{239240}$, and Americium ${ }^{241}$ Results.

\begin{tabular}{|c|c|c|c|c|}
\hline Sample & $\begin{array}{c}\mathrm{Pu}^{238} \\
(\mu \mathrm{Ci} / \mathrm{g})\end{array}$ & $\begin{array}{l}\mathrm{Pu}^{239 / 240} \\
(\mu \mathrm{Ci} / \mathrm{g})\end{array}$ & $\begin{array}{c}\mathrm{Am}^{241} \text { (AEA) } \\
(\mu \mathrm{Ci} / \mathrm{g})\end{array}$ & $\begin{array}{c}\mathrm{Am}^{241}(\mathrm{GEA}) \\
(\mu \mathrm{Ci} / \mathrm{g})\end{array}$ \\
\hline $\begin{array}{l}\text { Core 51, } \\
\text { Segment 4L }\end{array}$ & $<1.70 \times 10^{-2}$ & 0.173 & NR & $<8.58 \times 10^{-2}$ \\
\hline $\begin{array}{l}\text { Core } 50 \text {, } \\
\text { drainable liquid } \\
\text { composite }\end{array}$ & $\begin{array}{c}<9.01 \times 10^{-5} \\
\mu \mathrm{Ci} / \mathrm{mL}\end{array}$ & $\begin{array}{c}6.57 \times 10^{-5} \\
\mu \mathrm{Ci} / \mathrm{mL}\end{array}$ & $\begin{array}{c}4.03 \times 10^{-5} \\
\mu \mathrm{Ci} / \mathrm{mL}\end{array}$ & $\begin{array}{l}7.33 \times 10^{-3} \\
\mu \mathrm{Ci} / \mathrm{mL}\end{array}$ \\
\hline $\begin{array}{l}\text { Core } 51 \text {, } \\
\text { drainable liquid } \\
\text { composite }\end{array}$ & $\begin{array}{c}0.0250 \\
\mu \mathrm{Ci} / \mathrm{mL}\end{array}$ & $\begin{array}{c}0.0114 \\
\mu \mathrm{Ci} / \mathrm{mL}\end{array}$ & $\begin{array}{l}0.000204 \\
\mu \mathrm{Ci} / \mathrm{mL}\end{array}$ & $\begin{array}{c}<3.30 \times 10^{-2} \\
\mu \mathrm{Ci} / \mathrm{mL}\end{array}$ \\
\hline $\begin{array}{l}\text { Core } 52 \text {, } \\
\text { drainable liquid } \\
\text { composite }\end{array}$ & $\begin{array}{c}<1.71 \times 10^{-4} \\
\mu \mathrm{Ci} / \mathrm{mL}\end{array}$ & $\begin{array}{c}<6.70 \times 10^{-5} \\
\mu \mathrm{Ci} / \mathrm{mL}\end{array}$ & $\begin{array}{l}0.00007 \\
\mu \mathrm{Ci} / \mathrm{mL}\end{array}$ & $\begin{array}{c}<5.90 \times 10^{-3} \\
\mu \mathrm{Ci} / \mathrm{mL}\end{array}$ \\
\hline $\begin{array}{l}\text { Core } 51 \text {, core } \\
\text { solids composite }\end{array}$ & 0.0166 & 0.117 & 0.0113 & $<6.14 \times 10^{-2}$ \\
\hline $\begin{array}{l}\text { Core } 52, \text { core } \\
\text { solids composite }\end{array}$ & $<1.65 \times 10^{-2}$ & 0.183 & 0.0168 & $<8.73 \times 10^{-2}$ \\
\hline
\end{tabular}

$\mathrm{DL}=$ Detection limit

NR = Analysis not required

\subsubsection{Uranium Analysis}

Uranium analysis was performed on the drainable liquid composites and fusion digestions of the core solids composites and Core 51, Segment 4L. Analyses were performed using a laser fluorometer; results are shown in Table 4-14. The RPDs were under $25 \%$ for all samples except the replicate analyses for the Core 51 core composite, which had an RPD of $88 \%$.

Table 4-14. Uranium Results.

\begin{tabular}{|l|c|}
\hline \multicolumn{1}{|c|}{ Sample } & $\begin{array}{c}\text { Uranium } \\
(\mu \mathrm{g} / \mathrm{g})\end{array}$ \\
\hline Core 50, Segment 4L & 7,440 \\
\hline \hline Core 50, drainable liquid composite & $95.3 \mu \mathrm{g} / \mathrm{mL}$ \\
\hline Core 51, drainable liquid composite & $588 \mu \mathrm{g} / \mathrm{mL}$ \\
\hline Core 52, drainable liquid composite & $40.6 \mu \mathrm{g} / \mathrm{mL}$ \\
\hline \hline Core 51, core solids composite & 26,300 \\
\hline Core 52, core solids composite & 18,900 \\
\hline
\end{tabular}




\subsubsection{Total Alpha Analysis}

Total alpha analysis was performed on the drainable liquid composites and the fusion and water digestions of the core solids composites. Total alpha results are shown in Table 4-15. The total alpha concentration frequently tends to be somewhat lower than the sum of the individual alpha emitters; the difference is likely due to absorption by the salt residue on the counting mounts. However, in this case, the total alpha results are higher than the sum of the alpha emitters $\left(\mathrm{U}^{238}, \mathrm{Pu}^{2391240}\right.$, and $\left.\mathrm{Am}^{241}\right)$. The ratio of total alpha to the sum of the alpha emitters ranges from 1.4 to 6.6 and does not appear to follow any pattern among the samples. The higher total alpha concentration may be due to (1) high counting error; (2) cross talk from $\mathrm{Cs}^{137}$ and $\mathrm{Sr}^{90} / \mathrm{Y}^{90}$; or (3) another isotope may be present which was not measured. All total alpha results are below the $50 \mu \mathrm{Ci} / \mathrm{g}$ dry sample required sensitivity of the Ferrocyanide DQO (Meacham et al. 1994).

Table 4-15. Total Alpha Results.

\begin{tabular}{|l|l|}
\hline \multicolumn{1}{|c|}{ Sample } & \multicolumn{1}{|c|}{$\begin{array}{c}\text { Total alpha } \\
(\mu \mathrm{Ci} / \mathrm{g})\end{array}$} \\
\hline Core 50, drainable liquid composite & $\begin{array}{c}0.000914 \\
\mu \mathrm{Ci} / \mathrm{mL}\end{array}$ \\
\hline Core 51, drainable liquid composite & 0.0166 \\
& $\mu \mathrm{Ci} / \mathrm{mL}$ \\
\hline Core 52, drainable liquid composite & 0.000511 \\
& $\mu \mathrm{Ci} / \mathrm{mL}$ \\
\hline \hline Core 51, core solids composite, water digestion & 0.000520 \\
\hline Core 51, core solids composite, fusion & 0.473 \\
\hline Core 52, core solids composite, water digestion & 0.00743 \\
\hline Core 52, core solids composite, fusion & 0.395 \\
\hline
\end{tabular}

\subsection{PHYSICAL ANALYSIS}

Bulk density measurements were performed on segments or subsegments, drainable liquid composites, and core solids composite samples; results are shown in Table 4-16. The bulk density measurement on the homogenized solids samples were around $1.5 \mathrm{~g} / \mathrm{mL}$. Several segments (Core 50, Segment 2; Core 51, Segment 3L; and Core 52, core solids composite) produced anomalous densities which were much lower $(1.2 \mathrm{~g} / \mathrm{mL})$ or higher $(1.7 \mathrm{~g} / \mathrm{mL})$ than the other solids samples. However, an average density for all solid segments, including the anomalous points, was $1.51 \mathrm{~g} / \mathrm{mL}$. Duplicate analyses were performed on the drainable liquid samples only; RPDs for these samples were less than $2 \%$. 
Table 4-16. Bulk Density Results.

\begin{tabular}{|l|c|}
\hline \multicolumn{1}{|c|}{ Sample } & Density (g/mL) \\
\hline Core 50, Segment 1R & IS \\
\hline Core 50, Segment 2 & 1.71 \\
\hline Core 50, Segment 3 & IS \\
\hline Core 50, Segment 4 & IS \\
\hline \hline Core 51, Segment 2 & IS \\
\hline Core 51, Segment 3U & 1.49 \\
\hline Core 51, Segment 3L & 1.70 \\
\hline Core 51, Segment 4U & 1.48 \\
\hline Core 51, Segment 4L & 1.53 \\
\hline \hline Core 52, Segment 1 & IS \\
\hline Core 52, Segment 2 & 1.55 \\
\hline Core 52, Segment 3U & 1.50 \\
\hline Core 52, Segment 3L & 1.52 \\
\hline Core 52, Segment 4 & IS \\
\hline \hline Core 50, drainable liquid composite & 1.02 \\
\hline Core 51, drainable liquid composite & 1.20 \\
\hline Core 52, drainable liquid composite & 1.11 \\
\hline \hline Core 51, core solids composite & 1.46 \\
\hline Core 52, core solids composite & 1.19 \\
\hline
\end{tabular}

IS = Insufficient sample for analysis

Only one particle size analysis was performed on the tank 241-T-107 core samples as only one stratum was visually observed in the waste. An aliquot from Core 50, Segment 2, was analyzed. The number distribution range was 0.5 to $8 \mu \mathrm{m}$ with a median of $0.85 \mu \mathrm{m}$ : about $90 \%$ of the particles appear to be $2 \mu \mathrm{m}$ or smaller. The volume distribution range was 0.10 to $150 \mu \mathrm{m}$ with a median of $32.97 \mu \mathrm{m}$ : less than $5 \%$ of the volume was made up of particles $2 \mu \mathrm{m}$ or smaller. Some particles may have been greater than $150 \mu \mathrm{m}$ but this number was the upper limit on the analyzer. 


\subsection{CONCLUSIONS AND RECOMMENDATIONS}

The results of the analysis of the three core samples from tank 241-T-107 have been compared to the primary, secondary, and tertiary data requirements of the Ferrocyanide Safety Issue DQO. The analytical results indicate that the fuel concentration in the tank will not support a self-sustaining (i. e., propagating) reaction.

With the exception of a piece of plastic recovered from Core 50, Segment 4, the DSC results for all waste samples exhibited no exothermic reactions. The plastic is not representative of the surrounding waste and was found not to react in the absence of air. The stability of the waste is also supported by the low cyanide and TOC concentrations observed in the waste. The analytical results suggest that an exothermic reaction in tank 241-T-107 is unlikely and the tank should be categorized as Safe. However, core sampling yielded insufficient recovery to meet the quarter-segment analysis requirement defined in the Ferrocyanide DQO (Meacham et al. 1994) and safety criteria document (Postma et al. 1994). A decision on the need to resample tank 241-T-107 will be made after more samples are taken from the remaining Ferrocyanide Watch List tanks. 
This page intentionally left blank. 


\subsection{REFERENCES}

Borsheim, G. L., and B. C. Simpson, 1991, An Assessment of the Inventories of the Ferrocyanide Watchlist Tanks, WHC-SD-WM-ER-133, Rev. 0, Westinghouse Hanford Company, Richland, Washington.

Ecology, EPA, and DOE, 1994, Hanford Federal Facility Agreement and Consent Order, as amended, Washington State Department of Ecology, U. S. Environmental Protection Agency, and U. S. Department of Energy, Olympia, Washington.

Hill, J. G., 1992, Tank Waste Remediation System Tank Waste Characterization Plan, WHC-SD-WM-PLN-047, Rev. 0, Westinghouse Hanford Company, Richland, Washington.

Meacham, J. E., J. W. Buck, C. M. Anderson, B. A. Pulsipher, J. J. Toth, P. J. Turner, R. J. Cash, G. T. Dukelow, and H. Babad, 1994, Data Requirements for the Ferrocyanide Safety Issue Developed Through the Data Quality Objectives Process, WHC-SD-WM-DQO-007, Rev. 0, Westinghouse Hanford Company, Richland, Washington.

Postma, A. K., J. E. Meacham, R. J. Cash, G. S. Barney, G. L. Borsheim, M. D. Crippen, D. R. Dickinson, D. W. Jeppson, M. Kummerer, J. L. McLaren, C. S. Simmons, and B. C. Simpson, 1994, Ferrocyanide Safety Program: Safety Criteria for Ferrocyanide Watch List Tanks, WHC-EP-0691, Westinghouse Hanford Company, Richland, Washington.

Rich, H. S., 1993, Sampling and Analysis of SST and DST Waste Tanks in Support of TWRS Fiscal Year 1993, Statement of Work, WHC-SOW-93-0002, Rev. 1, Westinghouse Hanford Company, Richland, Washington.

Silvers, K. L., and A. F. Noonan, 1993, Letter of Instruction for Third Core Sample From Tank T-107, (internal letter 7K220-93-012 to J. G. Kristofzski, February 19), Westinghouse Hanford Company, Richland, Washington.

Svancara, G. B., and K. N. Pool, 1993, WHC 222-S and PNL 325 Single-Shell Tank Waste Characterization, 241-T-107 Cores 50, 51, and 52 - Data Package and Validation Summaries, WHC-SD-WM-DP-042, Rev. 1, Westinghouse Hanford Company, Richland, Washington.

Winters, W. I., 1992, Technical Project Plan for 222-S Laboratory in Support of Tank Waste Remediation System Tank Waste Characterization Plan (WHC-SD-WM-PLN-047, Rev. O) and Statement of Work (WHC-SOW-93-0002), WHC-SD-WM-TPP-047, Rev. 0, Westinghouse Hanford Company, Richland, Washington. 
This page intentionally left blank. 


\section{DISTRIBUTION}

\section{Number of Copies}

\section{OFFSITE}

6 U.S. Department of Energy

EM-36, Trevion II

12800 Middlebrook Road

Germantown, MD 20874

James V. Antizzo

Charles O'Dell (5)

1 U.S. Department of Energy

Savannah River Operations Office

P.O. Box A

Aiken, SC 29808

Thomas C. Temple

1 Charles S. Abrams

1987 Virginia

Idaho Falls, ID 83404

1 David O. Campbell

102 Windham Road

Oak Ridge, TN 37830

1 Fred N. Carlson 6965 North 5th West

Idaho Falls, ID 83401

1 Billy C. Hudson 202 Northridge Court

Lindsborg, KS 67456

1 Arlin K. Postma

3640 Ballard Road

Dallis, OR 97338 


\section{DISTRIBUTION (continued)}

Number of copies

\section{OFFSITE}

1 William R. Prindle 1556 Crestline Drive

Santa Barbara, CA 93105

1 Alfred Schneider 5005 Hidden Branches Drive

Dunwoody, GA 30338

1 Air Products \& Chemicals, Inc. 7201 Hamilton Blvd

Allentown, PA 18195-1501

George E. Schmauch

1 Battelle Columbus Laboratories

505 King Avenue

Columbus, OH 43201-2693

James A. Gieseke

1 Brookhaven National Laboratory

Upton, NY 11973

Kamal K. Bandyopadhyay

1 Design Science, Inc.

163 Witherow Road

Sewickley, PA 15143

Gary Powers

1 Fauske and Associates, Inc.

16W070 W. 83rd St.

Burr Ridge, IL 60521

Hans K. Fauske 


\section{DISTRIBUTION (continued)}

\section{Number of copies}

\section{OFFSITE}

1 Florida State University

Department of Chemistry B-164

Tallahassee, FL 32306

Greg R. Choppin

1 Harvard University

295 Upland Avenue

Newton Highlands, MA 02161

Melvin W. First

1 Hazards Research Corporation

200 Valley Road, Suite 301

Mt. Arlington, NJ 07856

Chester Grelecki

3 Los Alamos National Laboratory

P.O. Box 1663

Los Alamos, NM 87545

Steve F. Agnew

Steve W. Eisenhawer

Thomas E. Larson

1 MIT/Department of Nuclear Engineering

77 Massachusetts Ave.

Room 24-102

Cambridge, MA 02139

Mujid S. Kazimi

1 Nuclear Consulting Services, Inc.

P.O. Box 29151

Columbus, OH 43229-0151

J. Louis Kovach 


\section{DISTRIBUTION (continued)}

\section{Number of copies}

\section{QFFSITE}

Oak Ridge National Laboratory

1 Emory D. Collins

P.O. Box 2008

7930, MS-6385

Oak Ridge, TN 37831-6385

1 Charles W. Forsberg

P.O. Box 2008

MS-6495

Oak Ridge, TN 37831-6495

1 Thomas S. Kress

P.O. Box 2009

9108, MS-8088

Oak Ridge, TN 37831-8088

1 Rice University

5211 Paisley

Houston, TX 77096

Andrew S. Veletsos

2 Sandia National Laboratories

P.O. Box 5800

Albuquerque, NM 87185

Dana A. Powers, MS-0744

Scott E. Slezak, MS-0741

3 Science Applications International Corporation 20300 Century Blvd, Suite 200-B

Germantown, MD 20874

Ray S. Daniels (3) 


\section{DISTRIBUTION (continued)}

Number of copies

OFFSITE

State of Washington

Department of Ecology

1 Michael T. Gordon

P. O. Box 47600

Olympia, WA $98504-7600$

1 Alex Stone

1105 W 10th Avenue; $\$ 236$

Kennewick, WA 99336-6018

1 University of South Carolina

Department of Electrical and Computer Engineering

Swearingen Engineering Center

Columbia, SC 29208

Joseph S. Byrd

1 University of Washington

Center for Process Analytical Chemistry

Chemistry Department BG-10

Seattle, WA 98195

Bruce R. Kowalski

1 Vanderbilt University

P.O. Box 1596, Station B

Nashville, TN 37235

Frank L. Parker

1 Waste Policy Institute

555 Quince Orchard Road, Suite 600

Gaitherburg, MD 20878-1437

Donald T. Oakley 


\section{DISTRIBUTION (continued)}

Number of copies

\section{ONSITE}

12 U.S. Department of Energy, Richland Operations Office

R. F. Christensen (4)

S7-54

R. E. Gerton (4)

S7-54

A. G. Krasopoulos

A4-81

Public Reading Room

H2-53

RL Docket File (2)

9 Pacific Northwest Laboratory

S. A. Bryan

P7-25

A. R. Felmy

K6-82

B. M. Johnson

K1-78

M. A. Lilga

P8-38

B. P. McGrail

K2-38

R. D. Scheele

P7-25

G. F. Schiefelbein

P8-38

D. M. Strachan

K2-44

Hanford Technical Library

P8-55

40 Westinghouse Hanford Company

H. Babad

S7-30

J. B. Billetdeaux

S7-16

D. C. Board

S1-57

G. L. Borsheim

R2-11

S. R. Moreno

B3-06

R. J. Cash (2)

S7-15

M. D. Crippen

L5-31

D. R. Dickinson

L5-31

G. T. Dukelow

S7-15

J. M. Grigsby

H4-62

M. E. Huda

R3-08

M. N. Islam

R3-08

D. W. Jeppson

L5-31

N. W. Kirch

R2-11

C. A. Kuhlman

B3-30 


\section{DISTRIBUTION (continued)}

\section{Number of Copies}

\section{ONSITE}

M. Kummerer

H4-62

J. M. McLaren

H0-34

J. E. Meacham

S7-15

N. J. Milliken

H4-62

A. F. Noonan

B1-40

M. A. Payne

S7-14

F. R. Reich

L5-63

L. M. Sasaki

R2-12

P. Sathyanarayana

R2-12

C. P. Schroeder

L7-06

B. C. Simpson

R2-12

H. Toffer

H0-38

B. D. Valenzuela

R2-12

W. T. Watson

H0-38

W. D. Winkelman

L5-55

D. D. Wodrich

R2-85

Central Files

L8-04

Document Processing and Distribution(2)

L8-15

EDMC

H6-08

Information Release Administration (3)

R1-05

TFIC

R1-20 
This page intentionally left blank. 